\title{
Neelipleona and Symphypleona (Collembola) from a Sampling in the Mesovoid Shallow Substratum of the Sierra de Guadarrama National Park (Madrid and Segovia, Spain): Taxonomy and Biogeography
}

\author{
Enrique Baquero $^{1,2, * \mathbb{C}}$, Rafael Jordana ${ }^{1(\mathbb{D})}$ and Vicente M. Ortuño ${ }^{2}(\mathbb{D}$ \\ 1 Department of Environmental Biology, Faculty of Sciences, University of Navarra, University Campus, \\ 31080 Pamplona, Spain; rjordana@unav.es \\ 2 Grupo de Investigación de Biología del Suelo y de los Ecosistemas Subterráneos, Departamento de Ciencias \\ de la Vida, Facultad de Ciencias, Universidad de Alcalá, 28801 Madrid, Spain; vicente.ortuno@uah.es \\ * Correspondence: ebaquero@unav.es
}

check for updates

Citation: Baquero, E.; Jordana, R.; Ortuño, V.M. Neelipleona and Symphypleona (Collembola) from a Sampling in the Mesovoid Shallow Substratum of the Sierra de Guadarrama National Park (Madrid and Segovia, Spain): Taxonomy and Biogeography. Insects 2021, 12, 266. https://doi.org/10.3390/insects12030266

Academic Editor: Tibor Magura

Received: 25 February 2021

Accepted: 17 March 2021

Published: 21 March 2021

Publisher's Note: MDPI stays neutral with regard to jurisdictional claims in published maps and institutional affiliations.

Copyright: (c) 2021 by the authors. Licensee MDPI, Basel, Switzerland. This article is an open access article distributed under the terms and conditions of the Creative Commons Attribution (CC BY) license (https:/ / creativecommons.org/licenses/by/ $4.0 /)$.
Simple Summary: The material for this study was obtained after intensive sampling in the colluvial mesovoid shallow substratum (MSS) of the Sierra de Guadarrama National Park using 33 subterranean sampling devices (SSD). The data were obtained from the first extraction of the traps between May and October of 2015. This paper presents the results for a small part of the total Collembola captured (4.4\% of the total for this sampling), namely, the Neelipleona and Symphypleona. Eleven species belonging to seven families were identified, two of which are new species. Based on the results of this study, and others previously published on Collembola of the MSS in the Sierra de Guadarrama National Park, the presence of epigeal and edaphic species is observed, which, in general, are not as abundant as the newly discovered species. The high abundance and extensive presence in the hypogean environment of most of the new species discovered are indicative that the MSS has a unique and distinct Collembola community.

Abstract: Megalothorax minimus (Neelidae) and Sphaeridia pumilis (Sminthurididae) had already been identified in surface sampling from Sierra de Guadarrama. In Europe, Sminthurinus gisini (Katiannidae) seems to be associated with environments at specific altitudes, and has little representation in this sampling. Pygmarrhopalites custodum Baquero and Jordana sp. nov. (Arrhopalitidae) coexists with two previously identified surface occurring species of the same family (P. elegans and Arrhopalites caecus). However, P. custodum is more abundant, indicating that it occupies an ecological niche tending to troglophile in the mesovoid shallow substratum (MSS). Moreover, it is also more abundant in the MSS of higher altitude corresponding to the bioclimatic zones cryo-oro-Mediterranean and oro-Mediterranean supra forest. Allacma cryptica Baquero and Jordana sp. nov. (Sminthuridae), is another species that had not been previously detected on the surface in the study area. A. cryptica is an addition to a genus which has eight described species. Gisinurus malatestai (Sminthuridae) appears well represented in the MSS, being a species present very occasionally in the Mediterranean area. Two species of the genera Sminthurides (Sminthurididae) and Fasciosminthurus (Bourletiellidae) have been found, but they could not have been identified to the species level. Finally, a few specimens of Dicyrtomina minuta (Dicyrtomidae), an abundant species on the surface, have been captured.

Keywords: springtails; new species; mesovoid shallow substratum (MSS); subterranean sampling devices (SSD); Iberian Peninsula

\section{Introduction}

Until recently, intensive studies on the mesovoid shallow substratum (MSS) were lacking. Environmental conditions in MSS are similar to those of caves, but have a much 
more intense dependence on the ground and surface features. In karsts, caves and crevices form by either dissolution or fracture. Animals can be adapted and inhabit these systems, or move through the crevices and reach deep dwelling spaces. Gypsum areas offer similar opportunities to its own specific fauna [1].

Deep crevices or large cavities are generally absent in the granitic medium. Rocks broken and dislodged by surface weathering fall down and roll by gravity, coming to a rest along scree slopes or eventually accumulating in ravines and depressions, forming the MSS.

The MSS of the Sierra de Guadarrama (currently a National Park), being close to Madrid and therefore within easy reach of mainstream research institutions (universities, natural history museums) in the country, has been visited over a century by generations of researchers. Surprisingly though, few studies described the inner fauna of the MSS, and the question of whether such fauna was actually surface fauna that migrated inwards to seek refuge during the unfavorable seasons, or cavity-adapted fauna, was unsettled, prompting us to solve it.

We found that the faunal group contributing the greatest number of species and specimens was Collembola. In previous papers [2-4] we described the populations of the genus Orchesella and of the taxa Poduromorpha and Entomobryomorpha. In all three studies, the existence of a typical fauna of the MSS was demonstrated for this faunal group through the finding of large populations of hitherto unknown species, never found on the surface, alongside a few typically superficial species that always occurred in small numbers.

With the present study, we wanted to confirm whether the same phenomenon occurred for the Symphypleona, a group of Collembola that, with the exception of some species of the Arrhopalitidae family that can live both on the surface and in caves, is quite precisely epiphyllous or litter-dwelling. This would definitely confirm that MSS has its own characteristic fauna that is separate from the surface system.

\section{Materials and Methods}

\subsection{Site}

The sampling was conducted in the Sierra de Guadarrama National Park, located in the eastern half of the Central System (i.e., the Iberian Peninsula). The park covers 33,960 hectares, with a belt of $62,687.26$ hectares that functions as a peripheral protection area [5].

The Sierra de Guadarrama mountain range is configured in three axes comprised of the Siete Picos-La Mujer Muerta, Montes Carpetanos, and Cuerda Larga and associated mountainous complex (Figure 1). The dominant rocks are of metamorphic origin of the orthogneiss type [6]. Glacial and periglacial events fragmented this rock typology forming extensive colluvial deposits $[7,8]$ that make up numerous "scree slopes" that allowed the development of the MSS. The studied area is divided into three bioclimatic zones: supra-Mediterranean, oro-Mediterranean, and cryo-oro-Mediterranean [9,10]. The oro-Mediterranean zone is further sub-divided in forest and supra-forest. The most outstanding characteristics of these bioclimatic zones in the Sierra de Guadarrama, and its most conspicuous vegetation, are summarized in [11]. It should also be noted that there is intense snow precipitation in the cryo-oro-Mediterranean and oro-Mediterranean above the scrub supra-forest line.

\subsection{Methodology}

Thirty-three sampling points were established (Figure 1). The sampling was performed mainly using subterranean sampling devices (SSD) that consisted of a PVC cylinder $11 \mathrm{~cm}$ in diameter and $1 \mathrm{~m}$ in length, with perforations of $8 \mathrm{~mm}$ in diameter (with a separation of $15 \mathrm{~mm}$ between them) in its lower half, placed in a suitable substrate. A pitfall trap (10 cm in diameter), that fit within the PVC tube, was filled with 1,2-propanediol, and a vial containing cheese, was slid to the bottom of the tube, the top was closed and the entire unit was placed in the soil. Other details that describe the placement of traps and 
other methodology for capturing the animals have been described in [1]. The authors who performed the sampling included a team that consisted of V. M. Ortuño, E. Ledesma, J. D. Gilgado, A. Jiménez-Valverde, G. Pérez-Suárez, and E. Baquero. Permits to collect samples were obtained from the appropriate authorities (General Directorate of Environment of the Community of Madrid and Territorial Service of the Environment of the Junta de Castilla y León). Traps (Table 1) were placed between 20 May 2015 and 9 July 2015, and the first series of samples were obtained between 17 September 2015 and 6 November 2015.

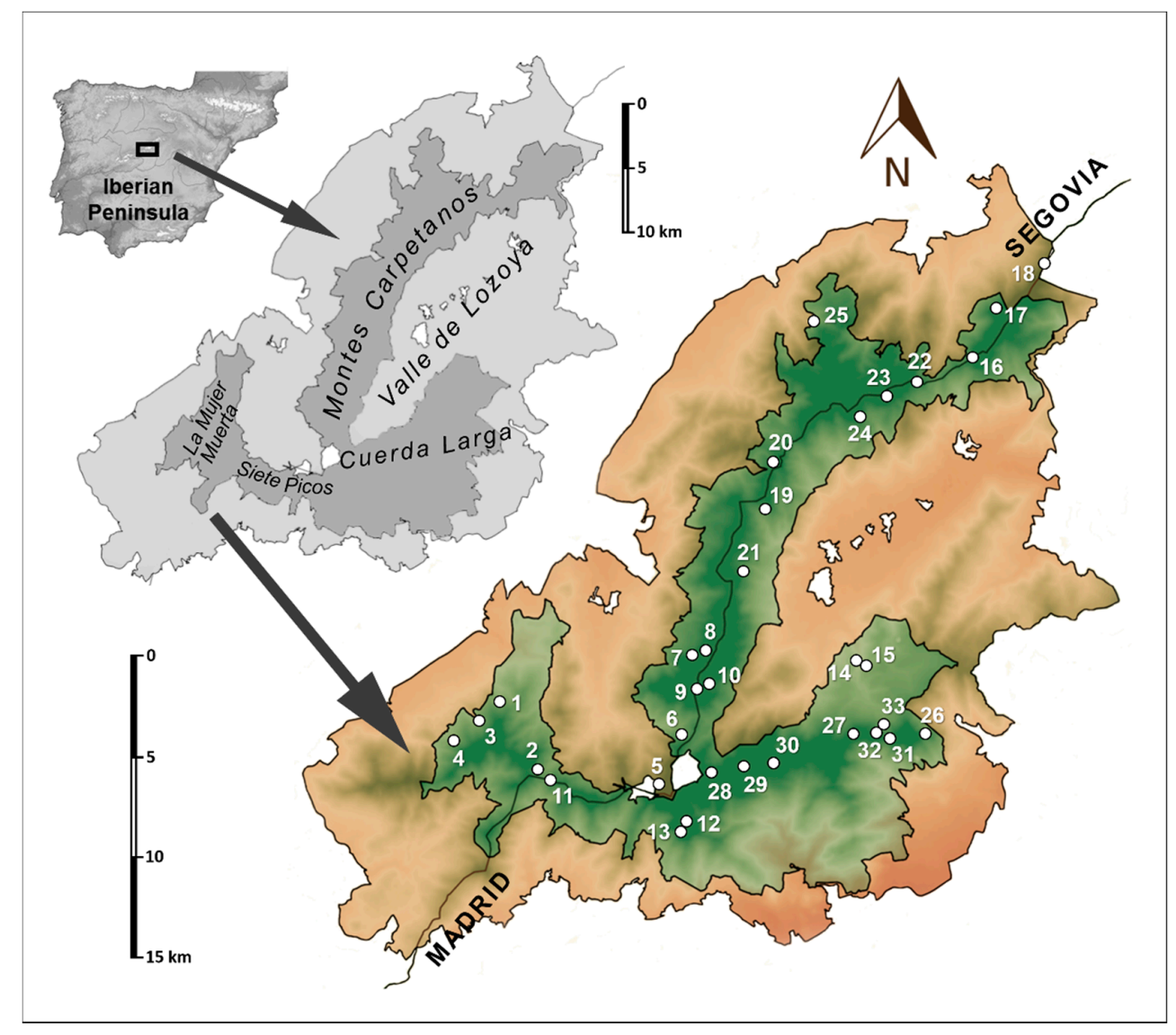

Figure 1. Sampling area in the Sierra de Guadarrama National Park, and locations of the subterranean sampling devices (SSD) used in the study of the Collembola.

After the preliminary sorting to separate the Neelipleona and Symphypleona from other Collembola, some representative specimens of each species were selected and mounted in Hoyer's medium for observation under a compound microscope (phase contrast and Differential Interference Contrast-DIC microscopy). A portion of the specimens were cleared in Nesbitt's fluid. The remaining samples were stored in $70 \%$ ethyl alcohol.

The terminology for Pygmarrhopalites Vargovitsh, 2009 [12] used in descriptions follows Fjellberg (1984) [13] for the outer maxillary palp; Nayrolles (1991) [14] for Ant III sensory organ; Bretfeld (1999) [15] for Abd VI; Christiansen (1966) [16] and Christiansen and Bellinger (1998) [17] for empodium; and Vargovitsh (2009) [12], for head, body, and legs. The material has been deposited at MZNA-Museum of Zoology at the University of Navarra (Pamplona, Spain).

The abbreviations used are: Abd—abdomen or abdominal segment; Ant—antennal segment or antenna/ae; a.s.l.—above sea level; MSS—-mesovoid shallow substratum; SSD— subterranean sampling devices. The chaetae are marked in bold in the text. 
Table 1. Location of traps (SSD, subterranean sampling devices).

\begin{tabular}{|c|c|c|c|c|c|c|c|}
\hline $\begin{array}{l}\text { Mountain Areas of the } \\
\text { Sierra de Guadarrama }\end{array}$ & Code & $\begin{array}{l}\text { UTM Coordinates } \\
(100 \times 100 \mathrm{~m})\end{array}$ & $\begin{array}{l}\text { Altitude } \\
\text { (m a. s. 1.) }\end{array}$ & Toponymy/Province & Date Installation of Traps & Date of Trap Recovery & Orientation \\
\hline \multirow{5}{*}{$\begin{array}{c}\text { Siete Picos—La Mujer } \\
\text { Muerta }\end{array}$} & SSD-1 & 30 T 408145204 & 1606 & Cancho del Río Peces/Segovia & 20 May 2015 & 17 September 2015 & North \\
\hline & SSD-2 & 30 T 410045166 & 1818 & Corrales de la Majada Minguete/Segovia & 20 May 2015 & 17 September 2015 & Northeast \\
\hline & SSD-3 & 30 T 406845192 & 1622 & Umbría de la Mujer Muerta/Segovia & 21 May 2015 & 17 September 2015 & North \\
\hline & SSD-4 & 30 T 405645181 & 1685 & Majada Conejo/Segovia & 21 May 2015 & 17 September 2015 & Northwest \\
\hline & SSD-11 & 30 T 410845161 & 1876 & Cerro Ventoso/Madrid & 9 June 2015 & 17 September 2015 & East \\
\hline $\begin{array}{c}\text { Puerto de los Cotos-Puerto } \\
\text { de Navacerrada }\end{array}$ & SSD-5 & 30 T 416645159 & 1923 & Arroyo Seco/Segovia & 27 May 2015 & 22 September 2015 & Northwest \\
\hline \multirow{10}{*}{ Montes Carpetanos } & SSD-7 & 30 T 418545229 & 1994 & Majada Hambrienta/Segovia & 2 June 2015 & 17 September 2015 & Northwest \\
\hline & SSD-8 & 30 T 419045231 & 2071 & Majada Aranguez/Segovia & 2 June 2015 & 17 September 2015 & Northwest \\
\hline & SSD-9 & $30 \mathrm{~T} 418745211$ & 2208 & Dos Hermanas/Madrid & 3 June 2015 & 5 October 2015 & East \\
\hline & SSD-10 & 30 T 419145213 & 2049 & Hoya de la Laguna Grande/Madrid & 3 June 2015 & 5 October 2015 & East \\
\hline & SSD-16 & 30 T 433445389 & 1956 & Las Revueltas-Los Horcos/Segovia & 23 June 2015 & 7 October 2015 & West \\
\hline & SSD-18 & $30 \mathrm{~T} 437345438$ & 1885 & Los Loberos/Segovia & 23 June 2015 & 7 October 2015 & Northwest \\
\hline & SSD-20 & 30 T 422645332 & 1937 & Cerro de Navahonda/Segovia & 24 June 2015 & 6 October 2015 & Northeast \\
\hline & SSD-23 & $30 \mathrm{~T} 428845367$ & 2144 & Circo del Pico Nevero/Madrid & 25 June 2015 & 6 October 2015 & Southeast \\
\hline & SSD-24 & 30 T 427445357 & 2042 & Peñacabra/Madrid & 25 June 2015 & 22 October 2015 & East \\
\hline & SSD-25 & 30 T 424945407 & 1731 & Arroyo del Charco (La Cepa)/Segovia & 2 July 2015 & 22 October 2015 & Northwest \\
\hline \multirow{8}{*}{$\begin{array}{c}\text { Cuerda Larga and } \\
\text { Associated Mountainous } \\
\text { complex }\end{array}$} & SSD-12 & 30 T 418045138 & 2102 & Collado del Piornal/Madrid & 9 June 2015 & 22 September 2015 & North \\
\hline & SSD-13 & 30 T 417945135 & 2113 & Los Almorchones_Las Buitreras/Madrid & 10 June 2015 & 22 September 2015 & Southwest \\
\hline & SSD-14 & 30 T 427445224 & 1406 & El Purgatorio/Madrid & 18 June 2015 & 5 October 2015 & West \\
\hline & SSD-15 & 30 T 427345224 & 1375 & Hueco de los Ángeles/Madrid & 18 June 2015 & 5 October 2015 & Northeast \\
\hline & SSD-26 & 30 T 430945186 & 1890 & La Najarra-Cuatro Calles/Madrid & 2 July 2015 & 30 October 2015 & East \\
\hline & SSD-27 & $30 \mathrm{~T} 427045185$ & 2101 & Bailaderos/Madrid & 2 July 2015 & 30 October 2015 & North \\
\hline & SSD-28 & $30 \mathrm{~T} 419345164$ & 2156 & Collado de Valdemartín/Madrid & 3 July 2015 & 6 November 2015 & North \\
\hline & SSD-32 & $30 \mathrm{~T} 428545187$ & 1948 & Arroyo de La Najarra/Madrid & 9 July 2015 & 22 October 2015 & Northeast \\
\hline
\end{tabular}




\section{Results}

\subsection{Summary}

Neelipleona and Symphypleona accounted for $4.4 \%$ of the Collembola captured in the traps (1860 specimens) in the total number of samples used to obtain data for this study (42,745 specimens). Specimens of nine genera and eleven species, belonging to seven families (Neelidae, Sminthurididae, Katiannidae, Arrhopalitidae, Sminthuridae, Bourletiellidae, and Dicyrtomidae) were captured, but with unequal representation. One of the species, belonging to the genus Pygmarrhopalites and new to science, was overwhelmingly abundant (1532 specimens; 83\%) and had an extensive distribution; a second new species belonging to the genus Allacma Börner, 1906 [18], was poorly represented (45 specimens; 2\%), and had a more restricted distribution. The other species, with the exception of Gisinurus malatestai Dallai, 1970 [19], were almost anecdotal in terms of abundance and distribution.

\subsection{Taxonomy}

Class Collembola Lubbock, 1870 [20]

Neelipleona Massoud, 1971 [21]

Neelidae Folsom, 1896 [22]

\subsubsection{Megalothorax minimus Willem, 1900}

\section{Material Studied}

Spain, Sierra de Guadarrama, Segovia, SSD-2, two specimens on a slide (10); SSD-8, two specimens on a slide (10). Madrid, SSD-11, two specimens on a slide (09); SSD-32, one specimen on a slide (01). Ortuño et al. leg [23].

\section{Remarks}

Present in the Holarctic Region and tropics, and previously referred for Guadarrama by Selga (1971) [24].

\section{Ecology}

Very poorly represented in the MSS of the study area (Figure 2). Observed only in the oro-Mediterranean bioclimatic zone, both in the forest and supra-forest belts. However, it appears to have a wide spatial distribution in the Sierra de Guadarrama National Park, having been detected in the underground of all three mountainous axes (Figure 3A). This species is syntopic with some Symphypleona cited in this work: Sphaeridia pumilis, Allacma cryptica Baquero and Jordana sp. nov., Pygmarrhopalites elegans, Arrhopalites caecus, and Pygmarrhopalites custodum Baquero and Jordana sp. nov.

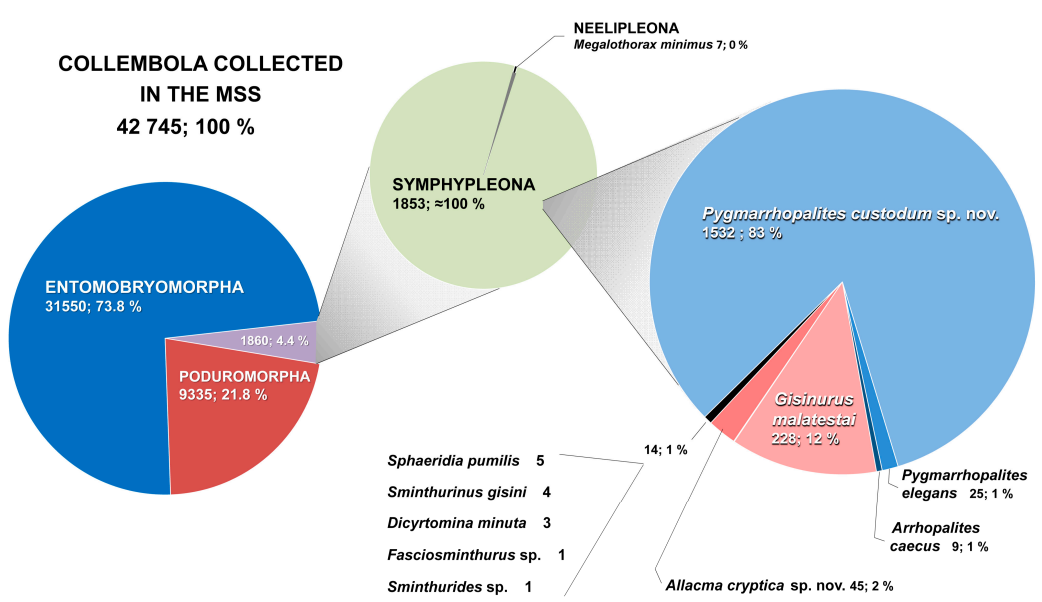

Figure 2. Diversity and abundance of Collembola collected in the MSS of the Sierra de Guadarrama National Park, with special emphasis of the Neelipleona and Symphypleona. 

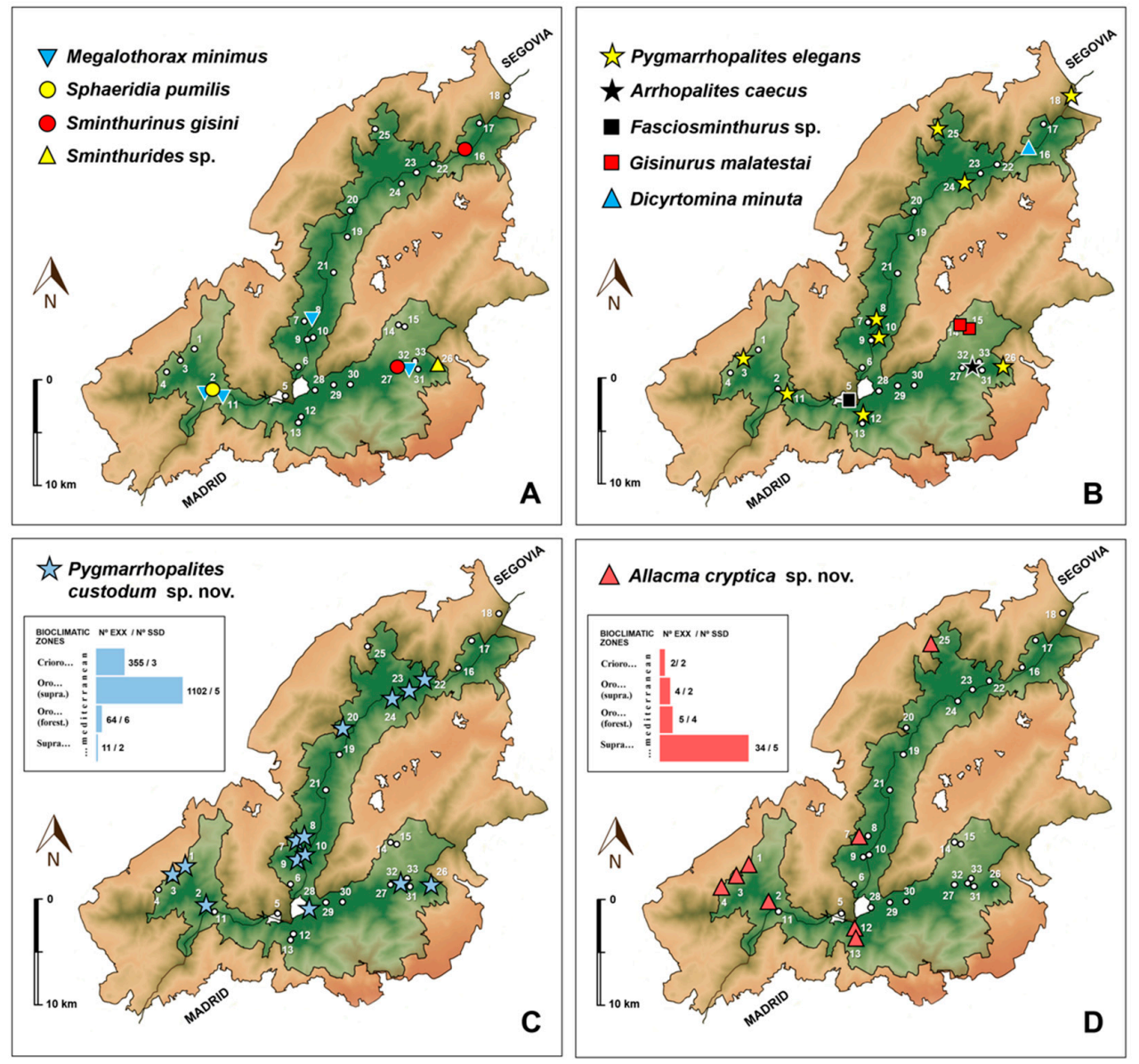

Figure 3. Distribution maps of Neelipleona and Symphypleona species collected in the mesovoid shallow substratum (MSS) of the Sierra de Guadarrama National Park.

Symphypleona Börner, 1901 [25], sensu Massoud 1971 [21]

Sminthurididae Börner, 1906 [18], sensu Betsch and Massoud 1970 [26]

\subsubsection{Sphaeridia pumilis (Krausbauer, 1898)}

Material Studied

Spain, Sierra de Guadarrama, Segovia, SSD-2, four specimens on a slide 03 and one on a slide 11. Ortuño et al. leg [27].

\section{Remarks}

Type locality: Germany. Present in the Holarctic Region and Australia. Previously cited for the Iberian Peninsula and in Guadarrama [15,28,29].

\section{Ecology}

Exclusively observed in one of the sampled locations near the Montón de Trigo mountain, part of the Mujer Muerta-Siete Picos mountainous axis (Figure 3A). The MSS is found in a colluvial deposit covered by pine forest (Pinus sylvestris) and located at an altitude slightly higher than $1800 \mathrm{~m}$ a.s.l., and therefore located in the oro-Mediterranean forest bioclimatic zone. In this MSS, it has been observed that S. pumilis is syntopic with Megalothorax minimus (Neelipleona), and the Symphypleona, Pygmarrhopalites custodum sp. nov. and Allacma cryptica Baquero and Jordana sp. nov.

Katiannidae Börner, 1913 [30], sensu Bretfeld 1999 [15] 


\subsubsection{Sminthurinus gisini Gama, 1965}

\section{Material Studied}

Spain, Sierra de Guadarrama, Segovia, SSD-16, one female and one male on a slide (05); Madrid, SSD-27, two juveniles on a slide (03). Ortuño et al. leg [31].

Remarks

Originally described from Portugal, and subsequently also found in the Czech Republic and Poland (Tatra Mountains), Slovakia (as S. carphathicus Rusek, 1966 [32]) and Austria [33-35], sometimes at specific altitudes, up to $1400 \mathrm{~m}$.

\section{Ecology}

Species poorly represented in the MSS samples (Figure 2). Found in the underground of two mountainous axes (Montes Carpetanos and Cuerda Larga) (Figure 3A), in the oro-Mediterranean forest and cryo-oro-Mediterranean bioclimatic zones. Syntopic with another Symphypleona, Dicyrtomina minuta.

Arrhopalitidae Stach, 1956 [36], sensu Bretfeld 1999 [15]

\subsubsection{Arrhopalites caecus (Tullberg, 1871)}

Material Studied

Spain, Sierra de Guadarrama, Madrid, SSD-32, one female on a slide (02) and eight in ethyl alcohol. Ortuño et al. leg [37].

Remarks

Palearctic species [15] described originally from Sweden, previously cited from Guadarrama [24].

Ecology

Found in a very low number of specimens of a single locality (oro-Mediterranean forest bioclimatic zone of the Cuerda Larga mountain axis). In this MSS, it has been observed that P. caecus is syntopic with Megalothorax minimus (Neelipleona), and Pygmarrhopalites custodum sp. nov. (Symphypleona).

\subsubsection{Pygmarrhopalites elegans (Cassagnau and Delamare-Deboutteville, 1953)}

Material Studied

Spain, Sierra de Guadarrama, Segovia, SSD-3, two females on a slide (08); SSD-08, one female on a slide (11); SSD-18, three specimens on a slide (02); SSD-25, one specimen on a slide (09) and four in ethyl alcohol; Madrid, SSD-10, one juvenile on a slide (01); SSD-11, one specimen on a slide (10) and seven in ethyl alcohol; SSD-12, one juvenile on a slide (08); SSD-24, two females on a slide (04); SSD-26, two females on a slide (03). All Ortuño et al. leg [38].

\section{Remarks}

Described originally from the south of the Iberian Peninsula [37], previously cited from Guadarrama [24].

\section{Ecology}

This species was not very abundant (25 specimens) (Figure 2) in the sample. However, while it has been observed very scarcely in the study area, it is widely distributed across the three mountainous axes of the Sierra de Guadarrama National Park (Figure 3B). This species is present in the subsoil of the three bioclimatic zones, but it appears better represented in the oro-Mediterranean (seven locations out of nine collected), both in the forest and supraforest belt. In this MSS it has been observed that P. elegans is syntopic with Megalothorax minimus (Neelipleona), and the Symphypleona Pygmarrhopalites custodum sp. nov., and Allacma cryptica Baquero and Jordana sp. nov. 
3.2.6. Pygmarrhopalites custodum Baquero and Jordana sp. nov. (http:/ / zoobank.org / 1139329B-EE8F-45D2-A29D-F935DF913018, accessed on 20 March 2021)

Figures 4-6, Table 2.

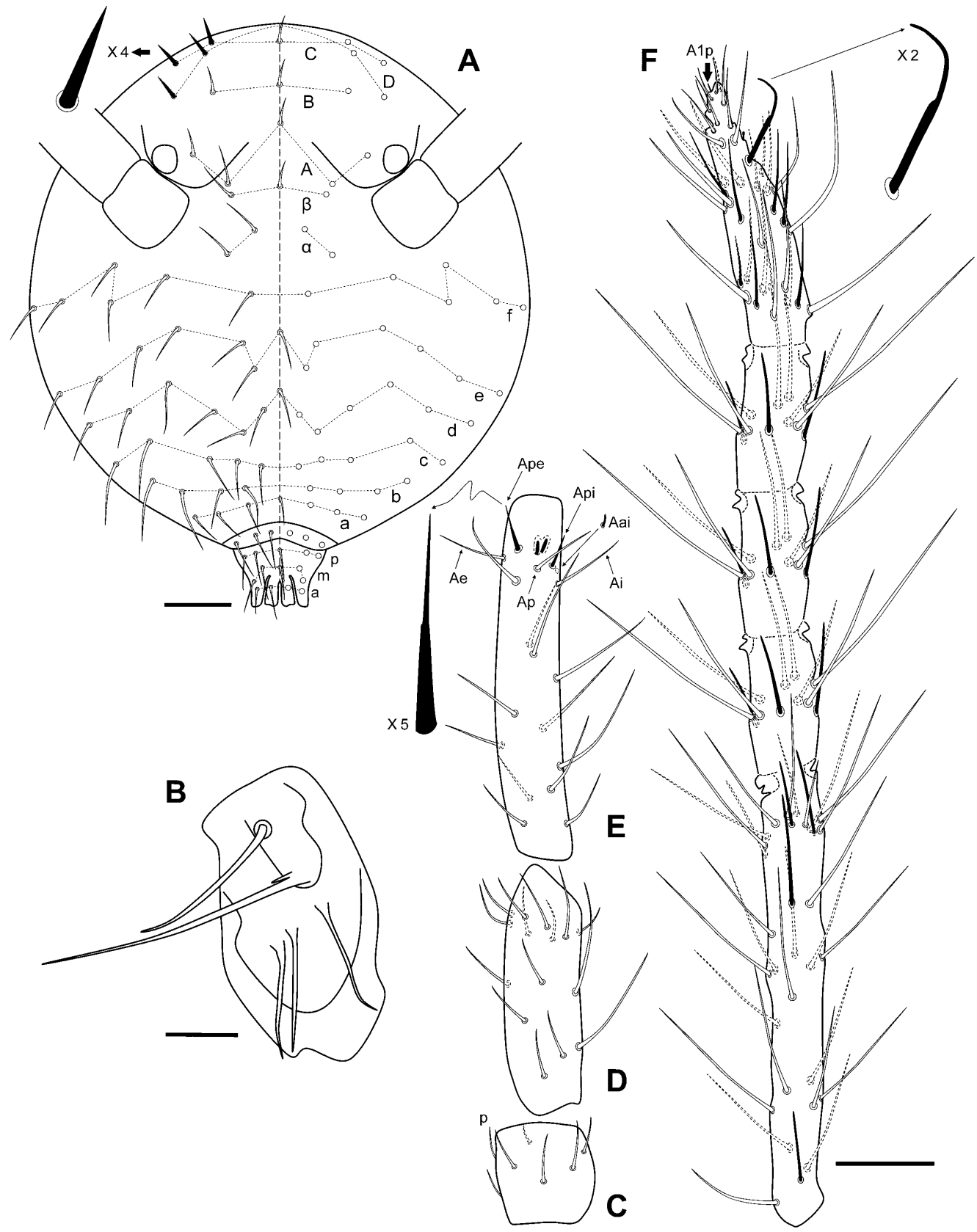

Figure 4. Pygmarrhopalites custodum Baquero and Jordana sp. nov.: (A) head, dorsal view; (B) maxillary palp and sublobal plate; (C-F) antennal segments I to IV (scale bars: A and C-F, $0.04 \mathrm{~mm}$; B, $0.01 \mathrm{~mm}$ ). 


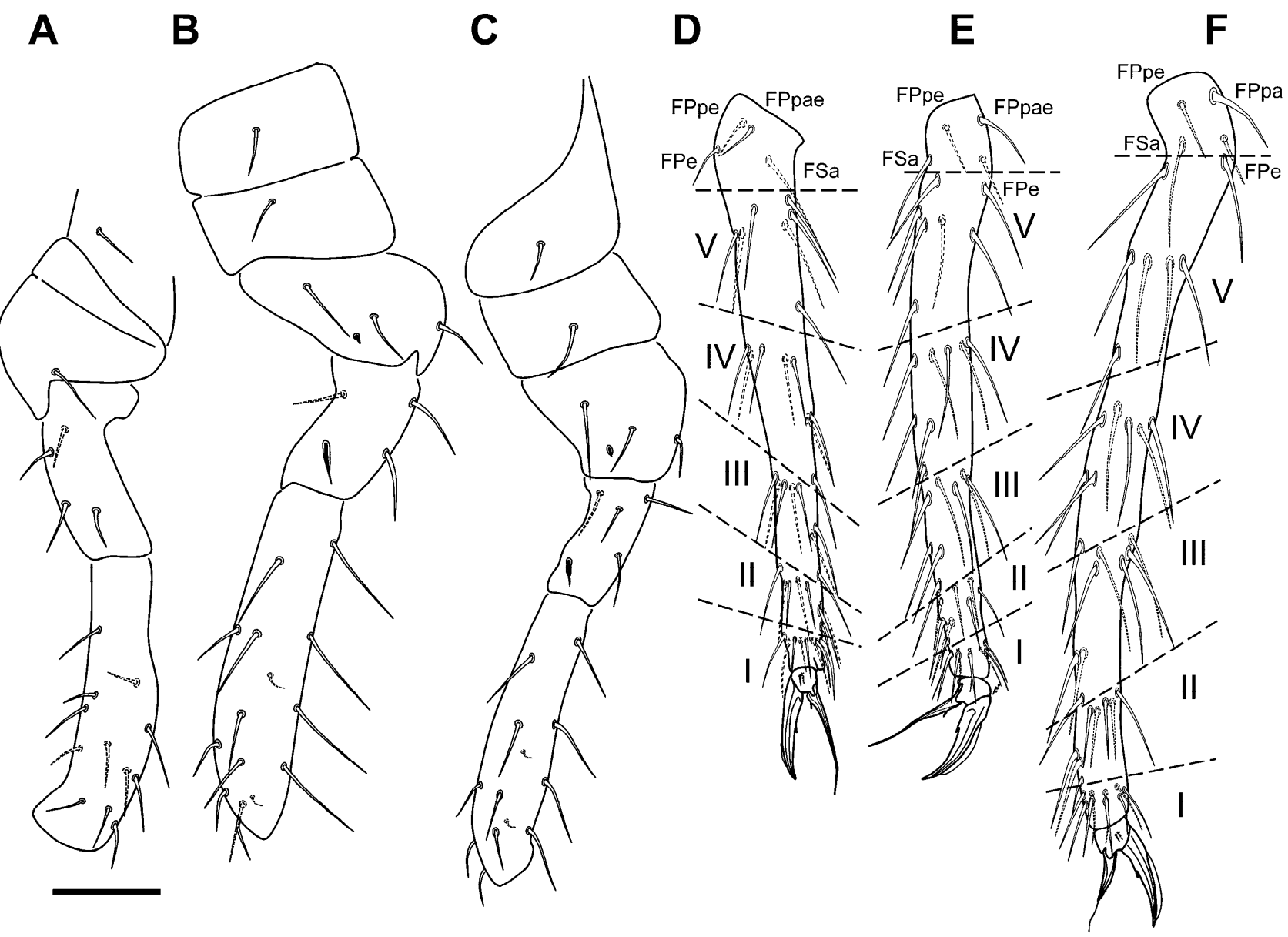

Figure 5. Pygmarrhopalites custodum Baquero and Jordana sp. nov.: (A-C) precoxa 1 to femur of legs 1 to 3 (L1, posterior view; L2-L3, anterior view); (D-F) tibiotarsus, claw, and empodium of L1 to L3 (all external view) (scale bar: $0.05 \mathrm{~mm}$ ).

Type Material

Holotype: female, SSD-20 (slide 03), Montes Carpetanos, Canchal del Cerro de Navahonda (30 T 422698 4533266, 1937 m a.s.l.), Sierra de Guadarrama, Segovia, Spain, 6 October 2015, pitfall SSD (since 24 June 2015), Ortuño et al. leg. Paratypes. Segovia: SSD-7, one female on a slide (10) and 23 specimens in ethyl alcohol; SSD-8, one female and one juvenile on a slide (11) and 41 specimens in ethyl alcohol; SSD-20, five specimens in ethyl alcohol; SSD-22, one female and one juvenile on a slide (09); Madrid: SSD-9, two females on a slide (03) and 146 specimens in ethyl alcohol; SSD-10, two females, one male and one juvenile on a slide (01) and approximately 300 specimens in ethyl alcohol; SSD-23, two females and one juvenile on a slide (05) and 136 specimens in ethyl alcohol; and SSD-24, one female and approximately 725 specimens in ethyl alcohol. Additional material, Segovia: SSD-1, one female on a slide (04) and nine specimens in ethyl alcohol; SSD-2, three females on three slides $(01,11$, and 12$)$ and 53 specimens in ethyl alcohol; SSD-3, one female on a slide (08); Madrid: SSD-26, one female on a slide (03); SSD-28, two females on a slide (01) and 66 specimens in ethyl alcohol; and SSD-32, one female on a slide (02).

\section{Diagnosis}

Eyes $1+1$. Bothriotricha ABC almost aligned. Ant IV with five distinctly separated sub-segments. Head dorsum with $4+4$ spine-like chaetae; three unpaired clypeal chaetae. All claws with tunica and inner tooth; empodia I-II with corner tooth, III with or without subterminal tooth; all empodia with filament, surpassing tips of corresponding claws. Manubrium with $7+7$ posterior chaetae; dens without ventral spines, two outer and one 
inner spines present; ventral dens formula: 3,2,1,1,0. Abd VI with winged and serrated circumanal chaetae, and anal appendage gutter-like with lateral and terminal fringes (last third approximately).
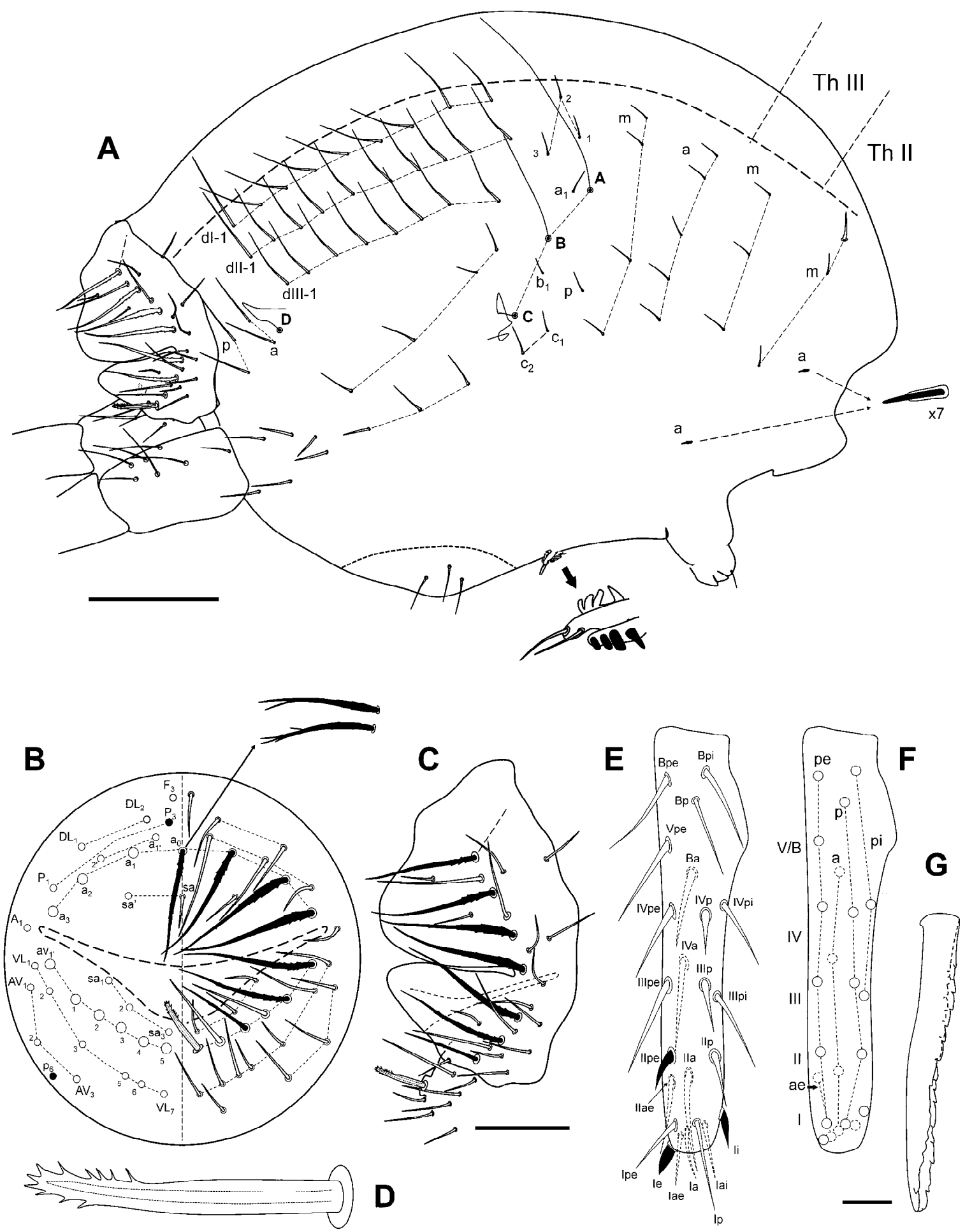

Figure 6. Pygmarrhopalites custodum Baquero and Jordana sp. nov.: (A) body, lateral view; (B) female anal valves schematized; (C) female anal valves, lateral view; (D) detail of the female anal appendage; (E) dens, posterior view; (F) dens, schematized; (G) mucro (scale bars: A, $0.1 \mathrm{~mm}$; B-C, $0.05 \mathrm{~mm}$; E-G, $0.02 \mathrm{~mm}$ ). 


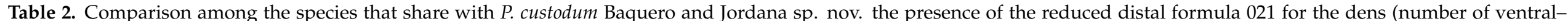

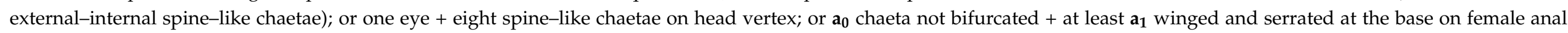
valves.

\begin{tabular}{|c|c|c|c|c|c|c|c|c|c|c|c|c|c|c|c|c|c|c|c|c|c|c|c|c|c|c|c|c|c|c|c|c|c|c|c|}
\hline Species/Character & 1 & 2 & 3 & 4 & 5 & 6 & 7 & 8 & 9 & 10 & 11 & 12 & 13 & 14 & 15 & 16 & 17 & 18 & 19 & 20 & 21 & 22 & 23 & 24 & 25 & 26 & 27 & 28 & 29 & 30 & 31 & 32 & 33 & 34 & D \\
\hline A. antrobius & 1 & 8 & U & 5 & 1 & 1 & 2 & 1 & 1 & 2 & 1 & 1 & 1 & $0^{*}$ & 2 & 0 & $5^{*}$ & $1^{*}$ & $1^{*}$ & 1 & $1^{*}$ & $1^{*}$ & $3^{*}$ & $1^{*}$ & $1^{*}$ & $1^{*}$ & $6^{*}$ & $0^{*}$ & 2* & $2^{*}$ & $2^{*}$ & $2^{*}$ & $2^{*}$ & $2^{*}$ & 18 \\
\hline A. macronyx & 1 & $0^{*}$ & 0 & $0^{*}$ & $0^{*}$ & $0^{*}$ & $0^{*}$ & $0^{*}$ & $0^{*}$ & $0^{*}$ & 0 * & 1 & $0^{*}$ & $0^{*}$ & $1-2$ & 0 & $0 *$ & $0 *$ & 0 & $0^{*}$ & 0 & 0 & $0^{*}$ & $0^{*}$ & 0 & 0 & $9^{*}$ & 0 & 3 & 3 & 3 & 3 & 3 & $1^{*}$ & 18 \\
\hline $\begin{array}{l}\text { A. potapovi } \\
\text { P cantaretulae }\end{array}$ & 1 & $\begin{array}{l}13 * \\
0 *\end{array}$ & ${ }_{0}^{1 *}$ & $\begin{array}{l}0 * \\
5\end{array}$ & $\begin{array}{l}1 \\
1\end{array}$ & 1 & 2 & 1 & 1 & 2 & 1 & $0-1$ & 1 & $0^{*}$ & $\frac{1}{2}$ & 1* & $5^{*}$ & $1^{*}$ & $1^{*}$ & 1 & $1 *$ & $1 *$ & $3^{*} *$ & $1^{*}$ & $1^{*}$ & $1^{*}$ & 5 & 0 & 3 & $2^{*}$ & 3 & 3 & 3 & $3 *$ & 16 \\
\hline $\begin{array}{l}\text { P. cantaceveruade } \\
\text { P. crepidinis }\end{array}$ & 1 & $0^{*}$ & $\begin{array}{l}0 \\
0 \\
0\end{array}$ & $\begin{array}{l}5 \\
5\end{array}$ & 1 & $\begin{array}{l}1 \\
1 \\
1\end{array}$ & $\frac{2}{2}$ & $\begin{array}{l}1 \\
1 \\
1\end{array}$ & $\begin{array}{l}1 \\
1\end{array}$ & $\begin{array}{l}2 \\
2\end{array}$ & $\begin{array}{l}1 \\
1\end{array}$ & $\begin{array}{l}1 \\
1 \\
1\end{array}$ & $\begin{array}{l}1 \\
1\end{array}$ & $\begin{array}{l}1 \\
1 \\
1\end{array}$ & $\begin{array}{l}2 \\
2\end{array}$ & $\begin{array}{l}0 \\
0\end{array}$ & $\begin{array}{l}2 \\
2\end{array}$ & $\begin{array}{l}2 \\
2\end{array}$ & $\begin{array}{l}0 \\
0\end{array}$ & $\begin{array}{l}1 \\
0-1\end{array}$ & $\begin{array}{l}0 \\
0\end{array}$ & $\begin{array}{l}0 \\
0\end{array}$ & $\begin{array}{l}3 * \\
0(1)\end{array}$ & $0(1)^{2} *$ & cit & cit & $\begin{array}{l}5 \\
5\end{array}$ & $\begin{array}{l}0 \\
0\end{array}$ & $2^{3}$ * & $\begin{array}{l}3 \\
2^{*}\end{array}$ & $\begin{array}{c}3 \\
2(4)^{*}\end{array}$ & $2^{2 *}$ & 告* & $1^{0}$ & ${ }_{8}^{6}$ \\
\hline $\begin{array}{l}\text { P. duari } \\
\text { P. dudichi }\end{array}$ & 1 & $11^{*}$ & U & $7^{* *}$ & 1 & 1 & 1* & $1{ }^{*}$ & 1 & $0^{*}$ & $1 *$ & 0 & $0^{*}$ & 1 & 2 & 0 & 2 & 2 & 0 & $2^{*}$ & 0 & 0 & 1 & $1^{*}$ & 0 & 0 & $8^{*}$ & 0 & $0^{*}$ & $1^{*}$ & $1^{*}$ & $1^{*}$ & $3^{*}$ & 0 & 13 \\
\hline 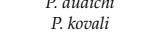 & $\begin{array}{l}1 \\
1\end{array}$ & $\begin{array}{l}8 \\
8\end{array}$ & $\begin{array}{l}0 \\
0 \\
0\end{array}$ & 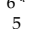 & 1 & 1 & ${ }_{1 *}^{2}$ & 1 & 1 & ${ }_{1 *}^{2}$ & 1 & $\begin{array}{l}1 \\
1\end{array}$ & 1 & ${ }_{1}^{1}$ & $\begin{array}{l}\mathrm{U} \\
2\end{array}$ & $\begin{array}{l}0 \\
0\end{array}$ & $\frac{2}{2}$ & $\frac{2}{2}$ & $\begin{array}{l}0 \\
0 \\
0\end{array}$ & ${ }_{2 *}^{1}$ & $\begin{array}{l}0 \\
0 \\
0\end{array}$ & $\begin{array}{l}0 \\
0 \\
0\end{array}$ & $\mathrm{U}^{\mathrm{U}}$ & $\begin{array}{l}\mathrm{U} \\
1^{*}\end{array}$ & $\begin{array}{c}\mathrm{U} \\
1^{*}\end{array}$ & $\begin{array}{c}\mathrm{U} \\
1^{*}\end{array}$ & $0_{8^{*}}^{* *}$ & $\mathrm{U}$ & $\mathrm{U}$ & $\mathrm{U}$ & $\mathrm{U}$ & $\mathrm{U}$ & $\mathrm{U}$ & $\mathrm{U}$ & ${ }_{13}^{5}$ \\
\hline $\begin{array}{l}\text { P. kristiani } \\
\text { P. }\end{array}$ & 1 & $0^{*}$ & 0 & 5 & $0^{*}$ & $0^{*}$ & 2 & $0^{*}$ & $0^{*}$ & $1^{*}$ & $0^{*}$ & 1 & 1 & $1-2$ & 1 & 0 & $1^{*}$ & 2 & 0 & $0^{*}$ & 0 & 0 & $0^{*}$ & $0^{*}$ & 0 & 0 & U & 0 & 3 & 3 & $2 *$ & $2^{*}$ & 1 * & 0 & 14 \\
\hline P. nigripes & 2? & 9* & 0 & $7^{*}$ & 1 & 1 & 2 & 1 & 1 & 2 & 1 & 1 & 1 & 1 & 2 & 0 & $4^{*}$ & 2 & 0 & 1 & $1^{*}$ & 1* & $3^{*}$ & $1 *$ & $1^{*}$ & $1^{*}$ & 2* & 0 & 3 & 3 & 3 & 3 & 3 & $3^{*}$ & 11 \\
\hline P. perezi & 1 & 8 & 0 & 5 & 1 & 1 & 2 & 1 & 1 & 2 & 1 & 1 & 1 & 1 & 2 & 0 & $3^{*}$ & 2 & $1^{*}$ & 1 & 0 & 0 & $3^{*}$ & $1^{*}$ & $1^{*}$ & $1^{*}$ & $1^{*}$ & 0 & 3 & 3 & 3 & 2* & 2* & $2 *$ & 10 \\
\hline 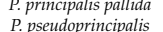 & $\begin{array}{l}1 \\
1\end{array}$ & $\begin{array}{l}8 \\
8\end{array}$ & $\begin{array}{l}0 \\
\mathrm{U}\end{array}$ & $\begin{array}{c}6 * \\
5\end{array}$ & $\begin{array}{c}0^{*} \\
1\end{array}$ & $\begin{array}{l}1 \\
1\end{array}$ & $\frac{2}{2}$ & $\begin{array}{l}1 \\
1\end{array}$ & $\begin{array}{l}1 \\
1\end{array}$ & $\begin{array}{l}2 \\
2\end{array}$ & $\begin{array}{l}1 \\
1\end{array}$ & $\begin{array}{l}1 \\
0\end{array}$ & $\begin{array}{l}1 \\
1\end{array}$ & $\begin{array}{l}1 \\
1\end{array}$ & $\begin{array}{l}2 \\
2\end{array}$ & $\begin{array}{l}\mathrm{U} \\
\mathrm{U}\end{array}$ & 等** & $\begin{array}{l}2 \\
2\end{array}$ & $1_{0}^{*}$ & ${ }_{2 *}^{1}$ & ${ }_{1 *}^{0}$ & ${ }_{1 *}^{0}$ & $3^{3 *}$ & 1* $1_{1 *}^{*}$ & 1** & $1_{1 *}^{*}$ & $2^{2 *}$ & $1_{0}^{*}$ & $\begin{array}{l}1^{*} \\
1^{*}\end{array}$ & $\begin{array}{l}1^{*} \\
1^{*}\end{array}$ & $1^{4 *}$ & $1^{4 *}$ & $1_{1 *}^{*}$ & $1^{*} *$ & 16 \\
\hline $\begin{array}{l}\text { P. salemensis } \\
\text { Pas }\end{array}$ & 1 & $0^{*}$ & 0 & 5 & 1 & 1 & 2 & 1 & 1 & 2 & 1 & $0-1$ & 1 & $\mathrm{U}$ & 2 & 0 & 2 & 2 & 0 & $2^{*}$ & 0 & 0 & $3^{*}$ & 2 & $1^{*}$ & 1 * & $2^{*}$ & 0 & 3 & 3 & 3 & 3 & 3 & 1 * & 7 \\
\hline $\begin{array}{c}\text { P. zloti } \\
\text { P. custodum pov. nov. }\end{array}$ & 1 & ${ }_{8}^{13 *}$ & $\begin{array}{l}0 \\
0 \\
0\end{array}$ & $\begin{array}{l}5 \\
5\end{array}$ & 1 & ${ }_{1}^{U}$ & 2 & 1 & $\begin{array}{l}\mathrm{U} \\
1\end{array}$ & $0_{2}^{*}$ & 1 & $\underset{0-1}{\mathrm{U}}$ & $0_{1}^{* *}$ & 1 & $\begin{array}{c}\mathrm{U} \\
1-2\end{array}$ & $\begin{array}{l}0 \\
0\end{array}$ & $\frac{2}{2}$ & $\frac{2}{2}$ & $\begin{array}{l}0 \\
0\end{array}$ & 1 & $\begin{array}{l}0 \\
0\end{array}$ & $\begin{array}{l}0 \\
0\end{array}$ & 1 & $1_{2}^{*}$ & $\begin{array}{l}0 \\
0\end{array}$ & $\begin{array}{l}0 \\
0\end{array}$ & $\begin{array}{l}\mathrm{U} \\
5\end{array}$ & $\begin{array}{c}\mathrm{U} \\
0 \text { or } 2\end{array}$ & $\mathrm{U}_{3}$ & $\begin{array}{l}\mathrm{U} \\
3\end{array}$ & $\mathrm{U}_{3}$ & $\mathrm{U}_{3}$ & $\mathrm{U}_{3}$ & $\begin{array}{l}\mathrm{U} \\
0\end{array}$ & 5 \\
\hline
\end{tabular}

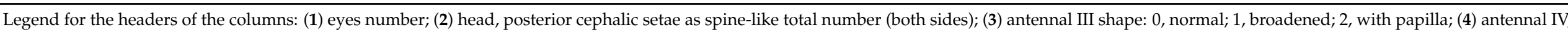

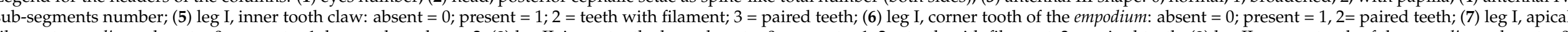

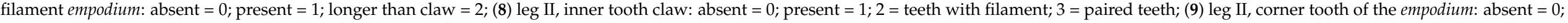

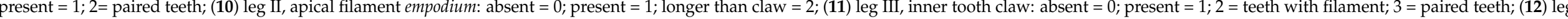

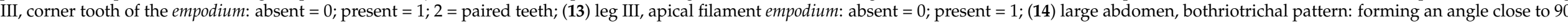

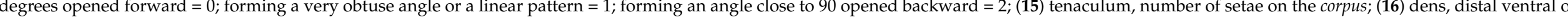

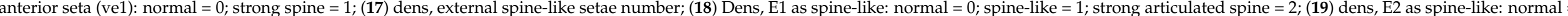

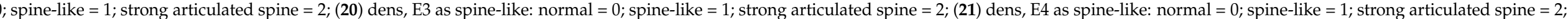

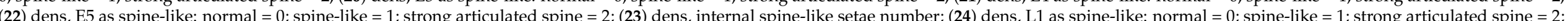

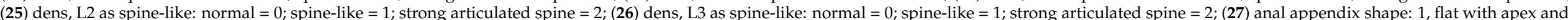

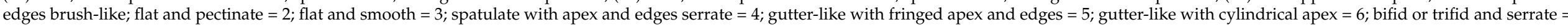

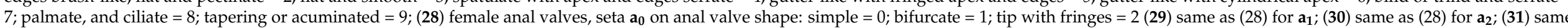

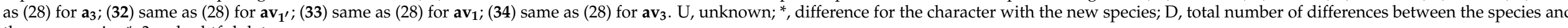
the new species $*$; , a doubtful data. 


\section{Description}

Female. Body length $0.95 \mathrm{~mm}$ (head excluded; $\mathrm{n}=18 ; 0.54$ to $1.0 \mathrm{~mm}$ ). Color pattern: pale white background.

Head. Eyes $1+1$, unpigmented. Clypeal area, row a: $3+$ axial +3 chaetae; row $\mathbf{b}$ : $4+4$; row c: with $5+5$ chaetae; row d: $6+$ axial +6 chaetae; row e: $6+$ axial +6 chaetae, row f: $6+6$ chaetae. Inter-antennal area, row $\alpha: 2+2$; row $\beta$ : $1+$ axial +1 . Lateral chaetae of rows $\mathbf{C}$ and $\mathbf{D}$ spine-like (Figure $4 \mathrm{~A}$ ). Chaetotaxy of the mouth region. Labrum: prelabral/labral chaetotaxy: 6/554. $2+2$ chaetae near the ventral groove. Maxilla: apical chaeta of the maxillary outer lobe (Figure $4 \mathrm{~B}$ ) with a short and thin subparallel branch at the base; sublobal plate with three sublobal hairs.

Antenna (Figure 4C-F) shorter than the body (ratio 0.80) and ratio Ant/head as 1.67 ( $\mathrm{n}=18)$; basal sub-segment of Ant IV 1.23 times longer than Ant III. Ant I with 7 chaetae, $\mathbf{p}$ as micro chaeta. Ant II with 15 chaetae, two interior ones longer than others. Ant III with 15 chaetae, the two usual sensilla, and three guard sensilla; Ant IV (Figure 4F) with five distinct sub-segments, with five evident whorls: one at the distal part of basal sub-segment; one on each of the three intermediate sub-segments; and another one at the basal part of the terminal sub-segment. Apical sub-segment with knobbed subapical organite and short chaeta-like A1p; one of the chaetae on this area has a narrowing since terminal half.

Foreleg (Figure 5A,D): precoxae 1, 2, and coxa with 1, 0, 1 chaetae, respectively. Trochanter with three anterior and 1 posterior chaetae. Femur with 12 chaetae, a4 turned perpendicularly to the longitudinal axis of the segment, $\mathbf{p} 1$ and $\mathbf{p} 3$ thin and short. Tibiotarsus with 43 chaetae: whorl I with 9 chaetae among which Ja curved and somewhat thickened, whorls II-V with 8, 8, 8, and 7 chaetae respectively; region F with 3 primary FP chaetae (e, ae, pe) and secondary chaeta FSa. Pretarsus with 1 anterior and 1 posterior chaetae. Foot complex: claw thin, with reduced tunica, with inner tooth and two pairs of indistinct lateral teeth; empodium thin, with corner tooth, and long apical filament surpassing the tip of the claw.

Mid leg (Figure 5B,E): precoxae 1 and 2 with 1, 1 chaetae respectively, precoxal process present, coxa with three chaetae and a microsensillum. Trochanter with three chaetae and a trochanteral organ. Femur with 15 chaetae, $\mathbf{p} 1$ and $\mathbf{p} 3$ very small. Tibiotarsus with 44 chaetae: whorl I with 9 chaetae, whorls II-IV with $8,8,8$, and 7 chaetae respectively; region F with three FP chaetae and FSa chaeta. Foot complex: claw wider than foreleg claw, with reduced tunica and inner tooth, and two pairs of small lateral teeth; empodium with corner tooth and long apical filament surpassing the tip of the claw.

Hind leg (Figure 5C,F): precoxae 1 and 2 with 1, 1 chaetae respectively, process on precoxa 1 present, coxa with three chaetae and a microsensillum. Trochanter with three chaetae and a trochanteral organ. Femur with 13 chaetae, p1 and p3 as micro chaetae. Tibiotarsus with 44: whorl I with 9 chaetae, whorls II-IV with 8, 8, 8, and 7 chaetae respectively; region $\mathrm{F}$ with three FP chaetae and FSa chaeta. Foot complex: claw wider than foreleg claw, with reduced tunica, inner tooth, and two pairs of small lateral teeth; empodium with or without a subapical small tooth, and a long apical filament surpassing the tip of the claw.

Large abdomen (Figure 6A): Th II with a single sensillum in row a and three chaetae in row $\mathbf{m}$ with $\mathbf{m}_{\mathbf{1}}$ bigger than other. Th III with a sensillum in row $\mathbf{a}$ and three chaetae in row $\mathbf{m}$. Abd row $\mathbf{a}$ with five chaetae, row $\mathbf{m}$ with four, and three $\mathbf{p}$ short chaetae, anterior to bothriotrichal complex. Bothriotrichal complex: ABC almost in a linear pattern; bothriotrichum $\mathbf{A}$ with one posterior accessory short chaeta $\left(\mathrm{a}_{1}\right)$; bothriotrichum $\mathbf{B}$ with one posterior accessory short chaeta $\left(\mathrm{b}_{1}\right)$; bothriotrichum $\mathrm{C}$ with two anterior accessory short chaetae ( $\mathbf{c}_{\mathbf{1}}$ and $\mathbf{c}_{\mathbf{2}}$ ). Posterior lateral complex with seven, and furca base complex with six chaetae. Posterior dorsal complex with three rows with 9, 10, and 8 long chaetae each. Ventral complex with three chaetae. Fifth abdominal segment: with two chaetae and bothriotrichum $\mathbf{D}$ in row $\mathbf{a}$, and two chaetae in row $\mathbf{p}$. Sixth abdominal segment (Figure $6 \mathrm{~B}, \mathrm{C})$ : Abd VI with broadened, winged, and serrated circumanal chaetae $\left(\mathbf{a}_{\mathbf{0}}, \mathbf{a}_{\mathbf{1}_{-3}}, \mathbf{a v}_{\mathbf{1}^{\prime}}\right.$ and $\mathbf{A V}_{1}$; sometimes such chaetae are only winged; in some specimens $\mathbf{a}_{0}$ has its tip simple, 
doble or four-branched); anal appendage gutter-like with lateral and terminal fringes (last third approximately) (Figure 6D).

Ventral tube with $1+1$ subapical chaetae.

Tenaculum with two apical chaetae on the corpus, three teeth, and a basal process on each ramus.

Furca (Figure 6E,F): manubrium with $7+7$ posterior chaetae. Dens (23 chaetae or spine-like chaetae): anterior side with 3, 2, 1, 1,0 chaetae; posterior side with Ie and IIpe as massive spines, Ii moderately spinous, IIIpi and IVpi not spine-like. Mucro (Figure 6G): both lamellae serrated forming a channel at the end. Dens about $1.4 \times$ as long as mucro.

Etymology. The name is derived from the Latin term custōs (guard, protector), (masculine name in genitive plural) in tribute and recognition of the people who work in the management and protection of the Sierra de Guadarrama National Park.

Remarks. The species that share with P. custodum sp. nov. the presence of the reduced distal formula 021 for the dens (number of ventral-external-internal spine-like chaetae); or one eye + eight spine-like chaetae on head vertex; or $\mathbf{a}_{0}$ chaeta not bifurcated + at least $\mathbf{a}_{1}$ winged and serrated at the base on female anal valves are: A. antrobius Yosii, 1954 (Japan) [39], A. macronyx Vargovitsh, 2012 (Abkhazia, Western Caucasus) [40], A. potapovi Vargovitsh, 2015 (Buryat Republic, Russia) [41], P. cantavetulae Jordana, Fadrique and Baquero, 2012 (Teruel, Spain) [42], P. crepidinis Jordana and Baquero, 2017 (Almería, Spain) (Jordana et al., 2017) [43], P. dbari Vargovitsh, 2017 (Abkhazia, Western Caucasus) [44], P. dudichi Loksa and Rubio, 1966 (Hungary) [45], P. kovali Vargovitsh, 2017 (Abkhazia, Western Caucasus) [44], P. kristiani Vargovitsh, 2005 (Ukraine) [46], P. nigripes Park and Kang 2007 (Korea) [47], P. perezi Arbea, 2013 (Jaén, Spain) [48], P. principalis pallida Linnaniemi, 1912 (Holarctic Region, boreo-alpine area) [49], P. pseudoprincipalis Vargovitsh, 2009 (Ukraine) [12], P. salemensis Soto-Adames and Taylor, 2013 (Illinois, USA) [50] and $P$. zloti Curcic and Lucic, 1997 (Zlotska Pecina Cave, Serbia) [51]. The species that share the presence of two external and one internal spines on dens, in addition to the new species being described, are: P. dbari, P. dudichi, P. crepidinis, and P. zloti; the first two have seven and six sub-segments on Ant IV; P. crepidinis and P. zloti have 0 and 13 spine-like chaetae on head vertex respectively. The remaining differences among these species are in Table 2.

Ecology. This is the Symphypleona species dominant in the MSS of the study area. This species was observed in 14 representative localities of the three mountainous axes, and therefore indicative of being widely distributed in the MSS of the Sierra de Guadarrama National Park (Figure 3C). Its abundance was truly remarkable, as they comprised 83\% (1532 specimens) of the specimens analyzed in this study (Figure 2). Mostly present in MSS of enclaves at altitudes close to $2000 \mathrm{~m}$ a.s.l., or higher, in the oro-Mediterranean supraforest and cryo-oro-Mediterranean bioclimatic zones; and less abundant at altitudes below $2000 \mathrm{~m}$ a.s.l., in the oro-Mediterranean forest and supra-Mediterranean zones (Figure 3C). Pygmarrhopalites custodum sp. nov. is syntopic with Megalothorax minimus (Neelipleona), and the Symphypleona Sphaeridia pumilis, Pygmarrhopalites elegans, Arrhopalites caecus, Allacma cryptica Baquero and Jordana sp. nov., and Sminthurides sp.

Sminthuridae Lubbock, 1862 [52] sensu Deharveng 2004 [53]

3.2.7. Allacma cryptica Baquero and Jordana sp. nov. (http:/ / zoobank.org/51419F2B-F4004AB8-B36B-FE7D1E111711, accessed on 20 March 2021)

Figures 7 and 8, Table 3.

\section{Type Material}

Holotype: female, SSD-12 (slide 07), Siete Picos-La Maliciosa, Canchal Collado del Piornal, north slope of La Maliciosa (30 T 418069 4513856, 2102 m a.s.l.), Sierra de Guadarrama, Madrid, Spain, 22 September 2015, pitfall SSD (since 9 June 2015), Ortuño et al. leg. Paratypes: Segovia, SSD-1, one male and one juvenile on two slides (02 and 07) and 26 specimens in ethyl alcohol; SSD-2, one female and one juvenile on two slides (01 and $11)$; SSD-3, one female and one juvenile on two slides (04 and 05) and two specimens in 
ethyl alcohol; SSD-4, one male and one juvenile on a slide (02); SSD-7, four juveniles on two slides (10 and 11); Madrid, SSD-13, one juvenile on a slide (06). Additional material: Segovia, SSD-25, one female and one male on a slide (10 and 11), and one specimen in ethyl alcohol.

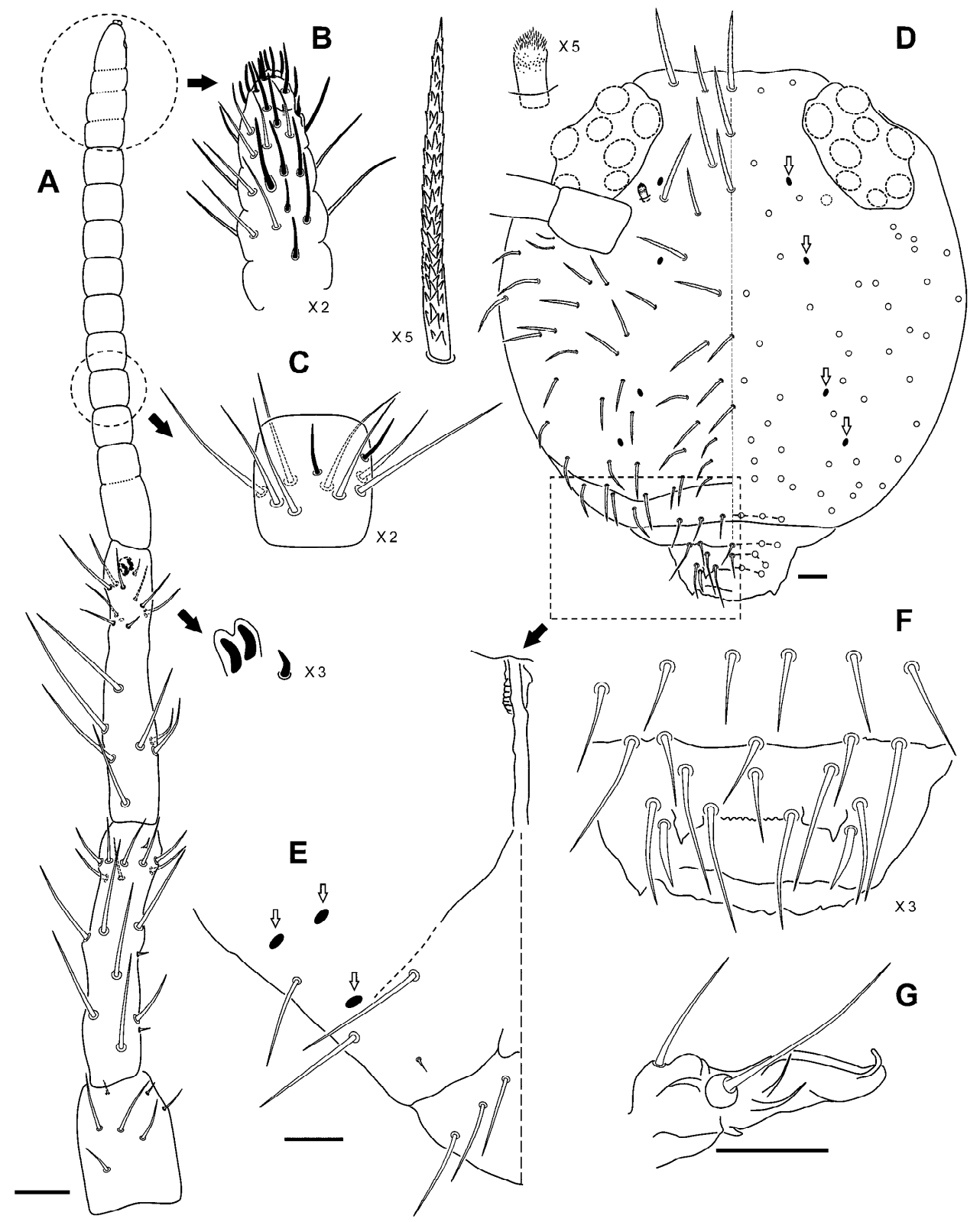

Figure 7. Allacma cryptica Baquero and Jordana sp. nov.: (A) antenna; (B) detail of the antennal tip; (C) detail of one of the Ant IV medial sub-segments (the remaining are similar); (D) head, dorsal view, with detail of one of the Mc from vertex and post-antennal special chaetae (oval organs pointed with white arrows); (E) head, partial ventral view to show the disposition of the three oval organs (white arrows); (F) labrum; (G) maxillary palp and sublobal plate (scale bars: all $0.05 \mathrm{~mm}$ ).

\section{Diagnosis}

Post-antennal chaeta long and slightly pointed, the sculpture of head vertex Mc scalelike and pointed, Ant II and III with 6-5 long chaetae each, 13-15 sub-segments on Ant IV, two unpaired clypeal chaetae, a conspicuous tooth on the ventral claw, tunica and serrated 
pseudonychia present, empodium without an internal tooth, dens anterior with $3,2,2,2,1 \ldots$ 1 chaetae, and anal appendage long, cylindrical, blunt, and without fringes.

\section{Description}

Female, head length 0.35-0.90 mm; body length 0.73-2.00 mm; antennal length 0.451.03; ratio Ant I/II/III/IV as $1 / 2.53 / 2.73 / 4.88(\mathrm{n}=4)$; male, head length $0.7 \mathrm{~mm}$; body 1.40-1.45 mm; antennal length $0.75-0.85 \mathrm{~mm}$; ratio Ant I/II/III/IV as $1 / 3.33 / 4.00 / 7.67$ $(n=3)$. Roughly uniform coloration, brownish violet, more intense dorsally in the large abdomen; head with more intense and reddish pigmentation, and antennae and legs, especially the first pair, darker and more violet.

Head. Ant II with 2-3 short ventral chaetae; Ant II and III with 6-5 long chaetae each; Ant IV with 13-15 sub-segments (Figure 7A-C). Eyes $8+8$. Head apex with rough chaetae; the remaining chaetae with a very diffuse ciliation; post antennal special chaetae long, pointed or rounded, with fine ciliation (Figure 7D). At least four dorsal and three ventral oval organs present (white arrows in Figure 7D,E). Labral formula 6/5,5,4 (Figure 7F). Maxillary outer lobe bifurcate, with two sublobal hairs (Figure 7G).
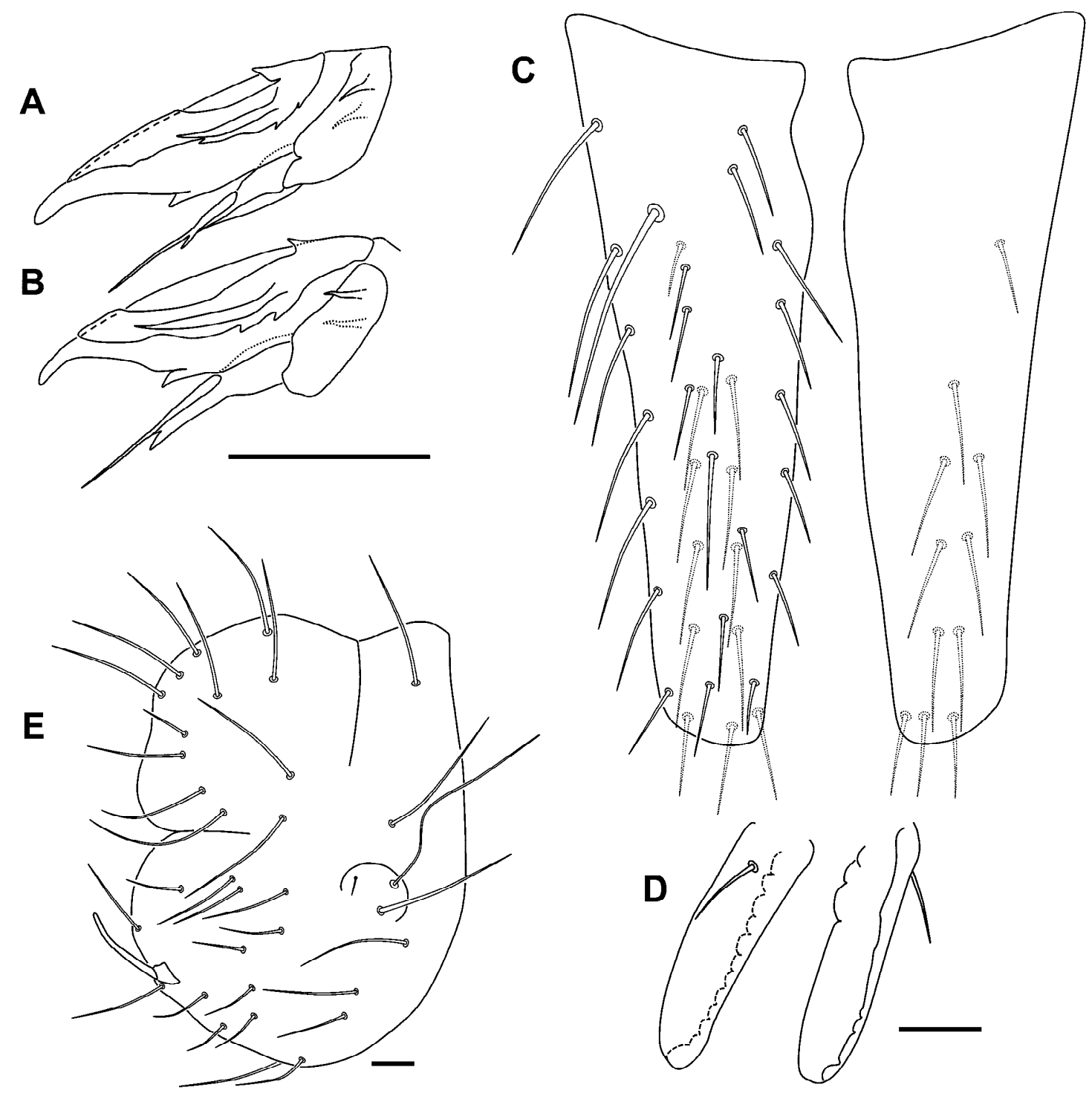

Figure 8. Allacma cryptica Baquero and Jordana sp. nov.: (A) claw of legs 1 and 2 (are similar), lateral view; (B) claw of leg 3; (C) dens, posterior view (at right, one of the dens of the Holotype, asymmetric); (D) mucro, anterior view at left, posterior view at right; (E) female anal valves, lateral view (scale bars: all $0.05 \mathrm{~mm}$ ). 


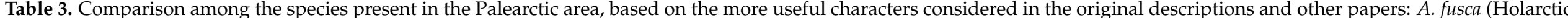
Region), A. gallica (described from France; occurrence: Western and Southern Europe, Mediterranean, North Africa) and A. koreana (Korea).

\begin{tabular}{|c|c|c|c|c|c|c|c|c|c|c|c|c|c|c|c|c|c|c|c|c|c|c|c|c|c|c|}
\hline Specie/Character & 1 & 2 & 3 & 4 & 5 & 6 & 7 & 8 & 9 & 10 & 11 & 12 & 13 & 14 & 15 & 16 & 17 & 18 & 19 & 20 & 21 & 22 & 23 & 24 & 25 & D \\
\hline A. fusca & 8 & 1 * & 3 & 5 & 5 & 15 & 1 * & 1 & 0 * & 1 & 1 * & $1 *$ & $1 *$ & $1 *$ & 2 & $6-8$ & 2 * & 2 & 2 & 2 & 1 & 0 & 1 & $1 *$ & $3 *$ & 10 \\
\hline A. gallica & 8 & 2 & 3 & $3 *$ & 5 & 13 & 2 & 0 * & 0 * & U & $0-1$ & $0-1$ & 1 * & 0 & $\bar{U}$ & $6-9$ & 2 * & 2 & 2 & 2 & 2 * & $1 *$ & 1 & 0 & $3 *$ & 8 \\
\hline A. koreana & 8 & $3 *$ & $\mathrm{U}$ & 4 & 4 & $12 *$ & 1 * & 1 & $0-1$ & 1 & 1 * & 1 * & 1 * & 0 & 3 & $7^{*}$ & 2 * & 2 & 2 & 2 & 1 & 0 & 1 & 0 & $4^{*}$ & 9 \\
\hline A. cryptica sp. nov. & 8 & 2 & $2-3$ & $4-5$ & $4-5$ & $13-15$ & 2 & 1 & 1 & 1 & 0 & 0 & 0 & 0 & $1-3$ & 6 & 3 & 2 & 2 & 2 & 1 & 0 & 1 & 0 & $1-2$ & \\
\hline
\end{tabular}

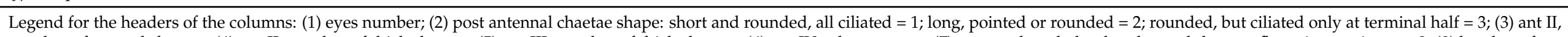

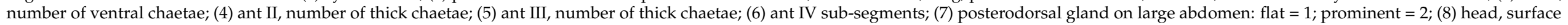

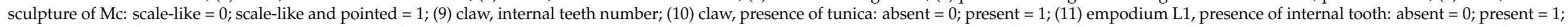

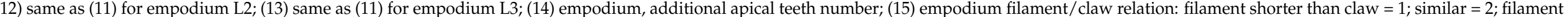

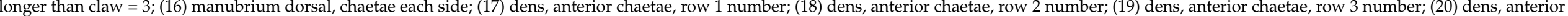

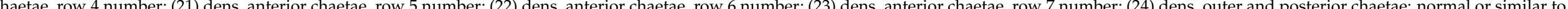

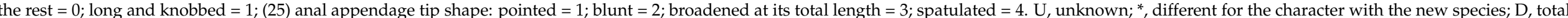
number of differences between the species and the new species. 
Body. Bothriotricha insertion linear or with a slightly obtuse open forward angle; bothriotrichum $\mathbf{D}$ inserted on small abdomen. Trochanter with a posterior spine-like chaeta. Claws broad, with tunica and serrated pseudonychia; inner tooth present on all legs; empodium of all legs without an internal tooth, pointed and acuminated, and with a filament not reaching the tip of claw on legs I-II, surpassing the claw on leg III; pretarsus with two chaetae (Figure 8A,B). Body with nearly smooth but broad chaetae. Tenaculum with two chaetae on the corpus. Manubrium with six dorsal chaetae, in three rows: three distal, two medial, and one proximal. Dens anterior with $3,2,2,2,1 \ldots 1$ chaetae (the Holotype, asymmetrically, has $3,2,2,2,2 \ldots 1$ ); posterior chaetae of normal length, with six internal, five external, eight medial and five proximal (Figure 8C). Mucro with smooth external and lobulated internal edge; mucronal chaeta present (Figure 8D). Small abdomen with normal chaetae, smooth and not broadened at its base; anal appendage long, cylindrical, blunt, and without fringes (Figure 8E).

Etymology. The new species is named cryptica, from the Latin crypticus, alluding to "hidden", referring to its subterranean life.

Remarks. The species with which the new species should be compared are $A$. fusca (Linnaeus, 1758) [54], A. gallica (Carl, 1899) [55], and A. koreana Yosii and Lee, 1963 [56]. A comparison among the above three and the new species, demonstrates differences in the head (post-antennal chaetae shape, vertex macrochaetae sculpture, macrochaetae number and number of sub-segments on the antenna), claws, empodium, dens, and anal appendage. The presence of a tooth on the internal claw in all legs allows the differentiation of the new species from $A$. fusca and A. gallica (A. koreana has it sometimes following Bretfeld 1999 [15]). Another definitive character, to differentiate the new species from $A$. fusca and A. gallica is the form of the anal appendage of the female, which in the case of the new species is acuminate while for the other three species it is broad and with a short ciliation. The principal differences among the new species and those previously described are schematized in Table 3.

Ecology. This species was observed in eight localities in the study area; present in the MSS of the three mountainous axes, although not very abundant (45 specimens, with a maximum collection/SSD of 16 specimens) (Figure 3D). However, while these data must be taken with caution given the small number of specimens collected, a trend is observed that it occurs at higher frequency in the MSS at lower altitudes, corresponding to the supra-Mediterranean and oro-Mediterranean forest bioclimatic zones (Figure 3D). Allacma cryptica Baquero and Jordana sp. nov. is syntopic with Megalothorax minimus (Neelipleona), and the Symphypleona Sphaeridia pumilis, Pygmarrhopalites elegans, and Pygmarrhopalites custodum sp. nov.

\subsubsection{Gisinurus malatestai Dallai, 1970}

Material Studied

Spain, Sierra de Guadarrama, Madrid, SSD-14, three females on two slides (04 and 05), and approximately 216 in ethyl alcohol; SSD-15, one female on a slide (06) and eight in ethyl alcohol. All Ortuño et al. leg [19].

Remarks

Originally described from Italy, but also found in France (caves) [57], Spain N [58] and Canary Islands [59], and Greece [57].

Ecology

Abundant species (228 specimens; 12\%; Figure 2) but very localized in the MSS of the Cascada de El Purgatorio area (Figure 3B), located in the Altos de la Morcuera (associated mountainous complex to the Cuerda Larga mountain axis). The two points sampled are located in the supra-Mediterranean bioclimatic zone. No data are available for other Symphypleona or Neelipleona syntopic with G. malatestai in the MSS. 
3.2.9. Sminthurides $\mathrm{sp}$.

Material Studied

Spain, Sierra de Guadarrama, Madrid, SSD-26, one juvenile on a slide (03). Ortuño et al. leg.

Remarks

It was not possible to determine the identity of the species because a single juvenile was available.

Ecology

According to the abundance (Figure 2) and distribution data (Figure 3A), the presence of this species in the MSS of the Sierra de Guadarrama National Park seems anecdotal. This species was found in a locality on the Cuerda Larga mountainous axis, and in the oro-Mediterranean forest bioclimatic zone.

Two other Symphypleona species, P. elegans, and P. custodum sp. nov., were found in the same locality.

Bourletiellidae Börner, 1913 [30], sensu Bretfeld 1994 [60]

\subsubsection{Fasciosminthurus sp.}

Material Studied

Spain, Sierra de Guadarrama, Segovia, SSD-5, one juvenile on a slide (05). Ortuño et al. leg.

Remarks

It was not possible to determine the identity of the species because a single juvenile was available.

Ecology

This species was found in a locality in the confluence of the three mountain axes, and in the oro-Mediterranean forest bioclimatic zone. According to the abundance (Figure 2) and distribution data (Figure 3B), the presence of this species in the MSS of the Sierra de Guadarrama National Park appears anecdotal.

Dicyrtomidae Börner, 1906 [17], sensu Deharveng 2004 [53]

3.2.11. Dicyrtomina minuta (Fabricius, 1783)

Material Studied

Spain, Sierra de Guadarrama, Segovia, SSD-16, three specimens on a slide (06). Ortuño et al. leg [61].

Remarks

A species with wide distribution, both in the Holartic region and in many localities in the southern hemisphere [15]. Until now it had only been identified in the north zone of the Iberian Peninsula [24,62,63] and Portugal S [64]; Selga (1971) [24] cited the subspecies D. minuta flavosignata in Madrid.

\section{Ecology}

The presence of this species in the MSS of the study area is almost anecdotal (Figure 2). It was only observed in the underground of a locality of the Cuerda Larga mountainous axis (Figure 3B), and in the oro-Mediterranean forest bioclimatic zone, being syntopic with another Symphypleona, S. gisini.

\section{General Discussion}

Previous intensive Collembola collection activities throughout the 20th century in the Sierra de Guadarrama were conducted in edaphic and epi-edaphic environments, and did not reveal the presence of these species except for S. pumilis [29], A. caecus [24] and 
P. elegans [24]. Of these species, S. pumilis has a surface habit, and the other two have been characterized as troglophiles [65]. Therefore, it came as no surprise that they might have been found in the MSS, which they could use as a refuge. Although cited here for the first time from the Sierra de Guadarrama, S. gisini and D. minuta are widely-distributed species and thus also likely seeking refuge in the MSS. However, as Figure 2 shows, it does not seem fortuitous that the most abundant species (P. custodum sp. nov., G. malatestai, A. crypticae sp. nov., P. elegans, and A. caecus) are all either troglobite or troglophilous species. Accounting for $83 \%$ of the combined abundance of Symphypleona, P. custodum sp. nov. is the dominant species of the group in the MSS of the Sierra de Guadarrama. It is seconded by G. malatestai, a very rare species in Europe that has been described as either superficial or troglophilous and found only in very sparse populations, but that in the MSS is rather abundant (223 ex.). We thus suspect that this species belongs to the MSS or caves proper. Allacma crypticae sp. nov. is the next most abundant species (45 ex.). The genus had never been cited in the Sierra de Guadarrama, and it also seems a characteristic species of the MSS.

The MSS has more moderate maximum and minimum temperatures than those found in the epigean environment, but this does not mean that the different MSS localities sampled in the study area are comparable. This circumstance is evidenced by the association of P. custodum sp. nov. with underground spaces. The number of specimens obtained for P. custodum sp. nov. ( $83 \%$ of the total of Symphypleona and Neelipleona collected) allows us to safely conclude that it has a preference in the MSS at higher altitudes (Figure 3C): cryo-oro-Mediterranean and oro-Mediterranean supra-forest ( $\approx 95 \%$ of specimens) vs. oro-Mediterranean forest and supra-Mediterranean ( $\approx 5 \%$ of specimens) (Figure 2$)$.

Our data indicate that the MSS has a unique and distinct Collembola fauna, constituting a new biotope for these Hexapoda. Epigean and edaphic species have also been collected in the MSS but, in general, they are less abundant and are less widespread in the underground of the studied area.

This study, comprises a new step toward a more thorough knowledge base and understanding of the MSS biocenosis. It demonstrates that the MSS region has enormous potential to serve as a refuge for surface and subterranean faunal species. Furthermore, it indicates that the management objectives for the MSS should include research of the biodiversity of its unique and distinct natural spaces.

Author Contributions: Conceptualization, E.B., R.J. and V.M.O.; funding acquisition, V.M.O.; methodology—sampling design, V.M.O.; methodology—sampling development, V.M.O. and E.B.; sorting (to species level) and mounting in Hoyer, R.J.; taxonomy, E.B. and R.J.; writing, E.B., R.J. and V.M.O.; preparation of the artwork, descriptions, E.B. and R.J., maps and graphics, V.M.O. All authors have read and agreed to the published version of the manuscript.

Funding: This work is part of a research project supported by the Spanish Ministry of Agriculture, Food and Environment-National Parks Autonomous Agency (http:/ / www.mapama.gob.es/es/ parquesnacionales-oapn/, accessed on 20 March 2021) SPIP2014-01143. The funders had no role in study design, data collection and analysis, decision to publish, or preparation of the manuscript.

Institutional Review Board Statement: Not applicable.

Data Availability Statement: Data are available upon request from the authors.

Acknowledgments: This work is part of the results of the project "Study of the diversity and distribution of animal species residing in the Surface Subterranean Environment of high mountain enclaves (Parque Natural de la Sierra de Guadarrama)". We must express our gratitude to the other members of the research team responsible for developing this project: Gonzalo Pérez-Suárez, Alberto Jiménez-Valverde, Alberto Sendra, Pablo Barranco, Alberto Tinaut, Enrique Ledesma, Luis Subías, and Juan José Hererro-Borgoñón. In addition, it should be recognized that the fieldwork could not have been completed without the valuable collaboration of the authorities responsible for the national park as well as other workers (biologists, forestry agents, and staff of the Oficina de Atención a la Población Local-Sector Lozoya and Centro de Visitantes-Peñalara). In particular, we extend our thanks to Patricia Riquelme, Pablo Sanjuanbenito, Juan A. Vielva, Javier Donés, Marisol Redondo, 
Ignacio Granados, Ángel Rubio, César Martín, José Carrillo, Miguel Ángel Palomar, Ángel Velasco, Germán Mato, Manuel Criado, Enrique Calvo, Federico Madejón, and Montserrat Sanz. The three anonymous reviewers provided excellent comments and suggestions that improved this paper.

Conflicts of Interest: The authors declare no conflict of interest.

\section{References}

1. Martínez, M.; Baquero, E.; Barranco, P.; Ariño, A.H.; Jordana, R. A new genus and species of Collembola from caves of south Iberian Peninsula (Collembola, Poduromorpha, Onychiuridae). Zootaxa 2004, 734, 1-15.

2. Baquero, E.; Ledesma, E.; Gilgado, J.D.; Ortuño, V.M.; Jordana, R. Distinctive Collembola communities in the Mesovoid Shallow Substratum: First data for the Sierra de Guadarrama National Park (Central Spain) and a description of two new species of Orchesella (Entomobryidae). PLoS ONE 2017, 12, e0189205. [CrossRef] [PubMed]

3. Jordana, R.; Baquero, E.; Ledesma, E.; Ortuño, V.M. Poduromorpha (Collembola) from a sampling in the mesovoid shallow substratum of the Sierra de Guadarrama National Park (Madrid and Segovia, Spain): Taxonomy and Biogeography. Zool. Anz. 2020, 285, 81-96. [CrossRef]

4. Baquero, E.; Jordana, R.; Ortuño, V.M. Distinctive Collembola Communities in the Mesovoid Shallow Substratum: Entomobryomorpha of the Sierra de Guadarrama National Park (Central Spain). Zoosystema 2021, 43, 37-78. [CrossRef]

5. MAPAMA. Red de Parques Nacionales. Sierra de Guadarrama: Ficha Técnica; Ministerio de Agricultura, Pesca y Alimentación: Madrid, Spain, 2017. Available online: http:/ / www.mapama.gob.es/es/red-parques-nacionales/nuestros-parques/guadarrama/fichatecnica/default.aspx (accessed on 30 April 2017).

6. Vialette, Y.; Casquet, C.; Fúster, J.M.; Ibarrola, E.; Navidad, M.; Peinado, M.; Villaseca, C. Geochronological study of orthogneisses from the sierra de Guadarrama (Spanish central system). N. Jb. Miner. Mh. 1987, 10, 465-479.

7. Sanz, C. Periglaciarismo en montaña: La Sierra de Guadarrama. In Atlas de Geomorfología; Martínez de Pisón, E., Ed.; Alianza Editorial: Madrid, Spain, 1986; pp. 239-254.

8. Pedraza de, J.; Carrasco, R.M. El glaciarismo Pleistoceno del Sistema Central. Enseñanza Ciencias Tierra 2005, 13, 278-288. Available online: http:/ / www.raco.cat/index.php/ECT/issue/archive (accessed on 15 January 2021).

9. Rivas-Martínez, S. Pisos bioclimáticos de España. Lazaroa 1984, 5, 33-43.

10. Rivas-Martínez, S.; Belmonte, D.; Cantó, P.; Fernández-González, F.; de la Fuente, V.; Moreno, J.M.; Sánchez-Mata, D.; Sancho, L.G.; Leopoldo, G. Piornales, enebrales y pinares oromediterráneos (Pino-Cytision oromediterranei) en el Sistema Central. Lazaroa 1987, 7, 93-124.

11. Ortuño, V.M.; Ledesma, E.; Jiménez-Valverde, A.; Pérez-Suárez, G. Studies of the mesovoid shallow substratum can change the accepted autecology of species: The case of ground beetles (Coleoptera, Carabidae) in the Sierra de Guadarrama National Park (Spain). Anim. Biodiv. Conserv. 2019, 42, 213-226. [CrossRef]

12. Vargovitsh, R.S. New cave Arrhopalitidae (Collembola: Symphypleona) from the Crimea (Ukraine). Zootaxa 2009, $2047,1-47$. [CrossRef]

13. Fjellberg, A. The maxillary outer lobe, an important systematic tool in Isotomidae (Collembola). Bull. Ann. Soc. R. Belge Entomolog. 1984, 114, 83-88.

14. Nayrolles, P. La chetotaxie antennaire des Collemboles Symphypleones. Trav. Lab. Ecobiol. Arth. Edaph. 1991, 6, 1-94.

15. Bretfeld, G. Synopses on Palaearctic Collembola, Volume 2. Symphypleona. Abh. Ber. Naturkundemus. Görlitz 1999, 71, 1-318.

16. Christiansen, K. The genus Arrhopalites (Collembola: Sminthuridae) in the United States and Canada. Int. J. Speleol. 1966, 2, 43-73. [CrossRef]

17. Christiansen, K.; Bellinger, P.F. The Collembola of North America, North of the Rio Grande, Part 4, Families Neelidae and Sminthuridae, 2nd ed.; Publications of the Grinnell College: Grinnell, IA, USA, 1998; pp. 1175-1520.

18. Börner, C. Das System der Collembolen nebst Beschreibung neuer Collembolen des Hamburger Naturhistorischen Museums. Mit. Natur. Mus. Hamburg 1906, 23, 147-188.

19. Dallai, R. Ricerche sui Collemboli. XIV. Le Alpi Apuane. Lav. Soc. Ital. Biogeogr. 1970, 1, 433-482. [CrossRef]

20. Lubbock, J. Notes on the Thysanura, Part III. Trans. Linn. Soc. Lond. 1870, 26, 295-304. [CrossRef]

21. Massoud, Z. Contribution à la connaissance morphologique et systématique des Collemboles Neelidae. Rev. Ecol. Biol. Sol. 1971, 8, 195-198.

22. Folsom, J.W. Neelus Murinus, representing a new thysanuran family. Psyche 1896, 7, 391-392. [CrossRef]

23. Willem, V. Un type nouveau de Sminthuride: Megalothorax. Ann. Soc. Ent. Belg. 1900, 44, 7-10.

24. Selga, D. Catálogo de los colémbolos de la Península Ibérica. Graellsia 1971, 24, 133-283.

25. Börner, C. Collembola of Khumbu Himal. Ergeb. Forsch. Nepal 1901, 4, 80-130.

26. Betsch, J.M.; Massoud, Z. Etudes sur les Insectes Collemboles. I.-Systematique, ultrastructure externe et ecologie du genre Jeannenotia Stach,1956 (Symphypleones, Sminthurididae n. comb.). Description de deux Collemboles nouveaux (Proisotoma et Sminthurides). Rev. Ecol. Biol. Sol 1970, 7, 153-225.

27. Krausbauer, T. Neue Collembola aus der Umgebung von Weilburg an der Lahn. Zool. Anz. 1898, 21, 495-499, 501-504.

28. Gama, M.M. Contribuçao para o estudio dos Colêmbolos do Arquipélago da Madeira. Mem. Estud. Mus. Zool. Univ. Coimbra 1959, 257, 1-42. 
29. Selga, D. Proisotoma (Collembola) de los suelos de Guadarrama con descripción de una nueva especie del mismo género. Bol. Soc. Esp. Hist. Nat. 1962, 60, 69-76.

30. Börner, C. Die Familien der Collembolen. Zool. Anz. 1913, 41, 315-322.

31. Gama, M.M. Sminthurinus gisini n. sp. provenant du Portugal (Insecta, Collembola). Rev. Ecol. Biol. Sol 1965, 2, $277-279$.

32. Rusek, J. Eine neue Sminthurinus-Art (Collembola) aus der Mittel-Slowakei. Acta Entomol. Bohemoslov. 1966, 63, 25-26.

33. Dunger, W. Beitrag zur Collembolenfauna des Bruby Jesenik-Gebriges (Altvatergebirge). Acta Mus. Sil. 1970, 19, 35-44.

34. Weiner, W.M. Collembola of the Pieniny National Park in Poland. Acta Zool. Cracov. 1981, 25, 417-500.

35. Bauer, R. Zur Zönologie und Phänologie granitblockbesiedelnder Collembolen. Zool. Anz. 1993, 5/6, $237-248$.

36. Stach, J. The Apterygotan Fauna of Poland in Relation to the World-Fauna of This Group of Insects. Family: Sminthuridae; Polska Akademia Nauk: Krakowie, Poland, 1956; pp. 1-287.

37. Tullberg, T.F. Forteckning öfver Svenska Podurider. Öfversigt af. Kongl. Vetenskaps-Akademiens. Förhandlingar 1871, 28 , 143-155.

38. Cassagnau, P.; Delamare-Deboutteville, C. Les Arrhopalites et Pararrhopalites d'Europe. (Collemboles Symphypleones Cavernicoles). Notes Biospeol. 1953, 8, 133-147.

39. Yoshii, R. Höhlencollembolen Japans I. Kontyu 1954, 20, 62-70.

40. Vargovitsh, R.S. New troglomorphic Arrhopalitidae (Collembola: Symphypleona) from the Western Caucasus. Zootaxa 2012, 3174, 1-21. [CrossRef]

41. Vargovitsh, R.S. Arrhopalites potapovi sp. nov. (Collembola, Symphypleona) from Russia. Zootaxa 2015, 3955, 101-112. [CrossRef]

42. Jordana, R.; Fadrique, F.; Baquero, E. The collembolan fauna of Maestrazgo caves (Teruel, Spain) with description of three new species. Zootaxa 2012, 3502, 49-71. [CrossRef]

43. Jordana, R.; Barranco, P.; Amezcua, A.; Baquero, E. Two new species of Collembola (Hexapoda) from Saliente Cave (Almería, Spain)—Deux nouvelles espèces de collemboles (Hexapoda) de grotte du Saliente (Almería, Espagne). Zoosystema 2017, 39, 103-115. [CrossRef]

44. Vargovitsh, R.S. Two new troglobiont Pygmarrhopalites species of the principalis group (Collembola: Arrhopalitidae) from the West Caucasus. Zootaxa 2017, 4250, 23-42. [CrossRef]

45. Loksa, I.; Rubio, I. Angaben zu den Kenntnissen über die Collembolenfauna des Bakony-Gebirges. Opusc. Zool. 1966, 6, 139-156.

46. Vargovitch, R.S. Arrhopalites kristiani sp. n. (Collembola, Arrhopalitidae) from a cave in Eastern Carpathians. Vestn. Zool. 2005, 39, 67-73.

47. Park, K.H.; Kang, J.S. Three new species of Arrhopalites (Collembola, Symphypleona, Arrhopalitidae) from Korea. Entomol. Res. 2007, 37, 157-162. [CrossRef]

48. Arbea, J. Los Colémbolos (Hexapoda, Collembola) subterráneos de Jaén. In Los Invertebrados de Hábitats Subterráneos de Jaén; Pérez-Fernández, T., Pérez Ruiz, A., Eds.; Grupo de Espeleología de Villacarrillo (G.E.V.): Jaén, Spain, 2013 ; pp. $104-186$.

49. Linnaniemi, W.M. Die Apterygotenfauna Finlands II. Specieller Teil. Acta Soc. Sci. Fenn. 1912, 40, 1-361.

50. Soto-Adames, F.N.; Taylor, S.J. New species and new records of springtails (Hexapoda: Collembola) from caves in the Salem Plateau of Illinois, USA. J. Cave Karst Stud. 2013, 75, 146-175. [CrossRef]

51. Curcic, B.P.M.; Lucic, L.R. Arrhopalites zloti, a new species of cave springtails (Sminthuridae, Collembola) from Serbia, Yugoslavia. Arch. Biol. Sci. 1997, 49, 31-32.

52. Lubbock, J. Notes on the Thysanura, Part I: Smynthuridae. Trans. Linn. Soc. Lond. 1862, 23, 429-448. [CrossRef]

53. Deharveng, L. Recent advances in Collembola systematics. In Proceedings of the 6th International Seminar on Apterygota, Siena, Italy, 13-17 September 2002; pp. 415-433.

54. Linnæus, C. Systema Naturæ per Regna tria Naturæ, Secundum Classes, Ordines, Genera, Species, cum Characteribus, Differentis, Synonymis, Locis; Tomus I, Editio Decima, Reformata, Holmiæ, (Laurentii Salvii); Lugduni: Apud J. B. Delamolliere: Lyon, France, 1758; pp. 1-824.

55. Carl, J.H. Über die Collembola der Schweiz. Rev. Suisse Zool. 1899, 6, 264-362.

56. Yoshii, R.; Lee, C. On some Collembola of Korea with notes on the genus Ptenothrix. Contrib. Biol. Lab. Kyoto Univ. 1963, 15, 1-37.

57. Betsch, J.M. Eléments pour une monographie des Collemboles Symphypléones (Hexapodes, Aptérigotes). Mém. Mus. natl. Hist. Nat. 1980, 116, 1-227.

58. Nayrolles, P. A standardized description of European Sminthuridae (Collembola, Symphypleona), 1: Genera Lipothrix, Gisinurus, and Caparainea. Bijdr. Dierkd. 1993, 63, 43-60. [CrossRef]

59. Gama, M.M. Colémbolos das Canárias (Insectos, Apterigotas). In Proceedings of the Actas III Congreso Ibérico de Entomología, Granada, Spain, October 1987; pp. 73-89.

60. Bretfeld, G. Sturmius epiphytus n. gen. n. spec. from Colombia, a taxon of the Symphypleona (Insecta, Collembola) with an unexpected character combination. Z. Zool. Syst. Evol. 1994, 32, 264-281. [CrossRef]

61. Fabricius, O. Beskrivelse over nogle lidet bekiendte podurer, og en besonderlig Loppe. Nye Saml. K. Dansk.Vid. Selsk. Skr. 1783, 2, 296-311.

62. Arbea, J.I.; Jordana, R. Estudio ecológico de la colembofauna de los suelos del Macizo de Quinto Real (Pirineos Occidentales) y descripción de dos especies nuevas: Anurida flagellata sp. n. y Onychiurus subedinensis sp. n. (Insecta, Collembola). Bol. Est. Cent. Ecología 1985, 28, 57-80.

63. Jordana, R.; Arbea, J.I.; Ariño, A.H. Catálogo de colémbolos ibéricos. Base de datos. Pub. Biol. Univ. Navarra 1990, $21,1-231$. 
64. Gama, M.M.; Lopes, C.M.; Nogueira, A. Etude comparée de populations de Collemboles de plusieurs biotopes de l'Algarve (Portugal). In Proceedings of the 3rd International Seminar on Apterygota, Siena, Italy, 21-26 August 1989; pp. 363-370.

65. Massoud, Z.; Thibaud, J.M. Essai de classification des Collemboles «cavernicoles» européens. In Proceedings of the 6 Congrès International de Spéléologie, Olomouc, Czechoslovakia, 31 August-18 September 1973; Volume 5, pp. 141-157. 